\title{
mütefekkir
}

Aksaray Üniversitesi İslami Illimler Fakültesi Dergisi

cilt / volume: 7 • sayı / issue: 14 • aralık / december 2020 • 421-440

ISSN: 2148-5631• e-ISSN: 2148-8134・DOI: 10.30523/mutefekkir.757894

الثوازن البيئي في الشريعة الإسلامية

İslam Hukukunda Ekolojik Denge

Environmental balance in Islamic law (sharia)

\section{Enes ELMEDENİ}

Dr.

alrhalanas@gmail.com | https://orcid.org/0000-0002-7415-6943

(i) Makale Bilgisi / Article Information:

Makale Türü / Article Type: Araştırma Makalesi / Research Article

Geliş Tarihi / Received: 07.06.2020

Kabul Tarihi / Accepted: 04.09.2020

Yayın Tarihi / Published: 31.12.2020

99 Atıf / Cite as: Elmedeni, Enes. “İslam Hukukunda Ekolojik Denge”. Mütefekkir $7 / 14$ (2020), 421440. https://doi.org/10.30523/mutefekkir.757894

(C) Telif / Copyright: Published by Aksaray Üniversitesi İslami İlimler Fakültesi / Aksaray University Faculty of Islamic Education, 68100, Aksaray, Turkey. Tüm Hakları saklıdır / All rights reserved.

厄ુ İntihal / Plagiarism: Bu çalışma hakem değerlendirmesinden geçmiș, bir intihal yazılımı ile taranmıştır. İntihal yapılmadığı tespit edilmiștir. This article has gone through a peer review process and scanned via a plagiarism software. No plagiarism has been detected. 


$$
\begin{aligned}
& \text { الملخص } \\
& \text { يتناول هذا البحث علاقة التوازن البيئي بالشريعة الإسلامية، فقد أصبحت قضية البيئة والمحافظة عليها من القضايا } \\
& \text { المهمة في عالمنا المعاصر؛ لأفها تمس حياة كل الناس على وجه الأرض، والمتتبع لكتب التراث الإسلامي لا يجد }
\end{aligned}
$$

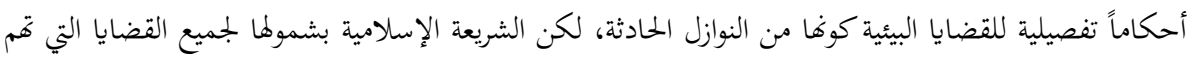

$$
\begin{aligned}
& \text { المسلم، ومرونتها لتصلح لكل زمان ومكان، تمتلك من النصوص، والمبادئ، والقواعد، ما يمكنها من مواكبة قضايا } \\
& \text { العصر الحادثة كقضية التوازن البيئي. ومن خلال البحث حاولت اظهار علاقة الشريعة الإسلامية بقضية التوازن } \\
& \text { البيئي عبر تقسيم الموضوع إلى خمسة أقسام: القسم الأول خصصته لبيان مفهوم التوازن البيئي، وارتباطه بالشريعة }
\end{aligned}
$$

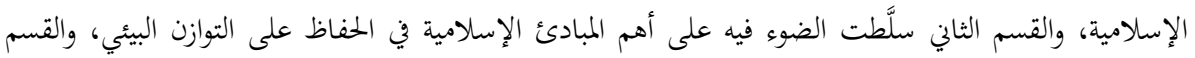

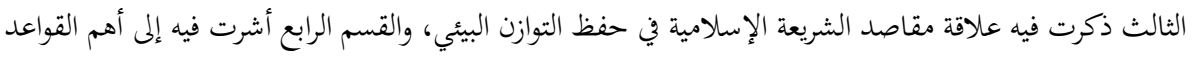

$$
\begin{aligned}
& \text { الفقهية، وتطبيقاما في التوازن البيئي، وأما القسم الأخير، فأبرزت فيه أهم وسائل تقويم الاختلال البيئي في الإسلام. } \\
& \text { الكلمات المفتاحية: الشريعة الاسلامية, الفقه, فقه البيئة, التوازن البيئي، الإسلام والبيئة. }
\end{aligned}
$$

\section{İslam Hukukunda Ekolojik Denge}

Öz

Bu araștırma ekolojik dengenin İslam hukuku ile ilişkisini ele almaktadır. Zira çevrenin ve ekolojik dengenin korunması yeryüzündeki tüm insanların hayatlarına dokunduğu için günümüz dünyasında önemli bir konu haline gelmiștir. İslam kültürüne dair kitaplarda çevre sorunlarıyla ilgili ayrıntılı hükümler bulmak zordur. Ancak Müslümanları ilgilendiren tüm konuları kapsamasından ve her zaman-mekâna uygun olma esnekliğinden dolayı İslam hukuku, ekolojik denge gibi güncel konulara ayak uyduracak metinlere, ilkelere ve kurallara sahiptir. İslam hukuku ile ekolojik denge konusu arasındaki ilişki, araştırma çerçevesinde beş bölüme ayırarak incelenmeye çalışılmıştır. İlk bölüm ekolojik denge kavramına ve İslam hukuku ile bağlantısına tahsis edilmiştir. İkinci bölümde ekolojik dengeyi korumadaki en önemli İslami ilkeler vurgulanmıș, üçüncü bölümde de İslam hukukunun ekolojik dengeyi korumadaki amaçları ele alınmıștır. Dördüncü bölümde ise bu konudaki en önemli fıkhî kurallardan ve bunların ekolojik dengedeki uygulamalarından bahsedilmiștir. Son bölümde ise bozulan ekolojik dengenin güçlendirilmesinin İslam'daki en önemli yollarına işaret edilmiştir.

Anahtar Kelimeler: İslam Hukuku, Fıkıh, Çevre Hukuku, Ekolojik Denge, İslam ve Çevre.

\section{Environmental balance in Islamic law (sharia)}

\section{Abstract}

This research deals with the relationship of environmental balance with Islamic law. Because it touches the lives of all people on earth, the issue of the environment and its preservation has become an important issue in our contemporary world. The followers of the Islamic heritage books do not find detailed provisions for environmental issues as they are current events (which are new to deal with). But Islamic law (sharia)with its flexibility that fits every time and place has inclusivity for all issues that concern Muslims, it has a lot of texts and principlesto go along with current issues in our contemporary world, as with environmental balance issue. Through this research I tried to find the 
relationship between Islamic law (sharia) and the environmental balance, by dividing the paper into five sections: The first one was devoted to explaining the concept of environmental balance and its connection to Islamic law. The second section is to focus on the most important Islamic principles in maintaining the environmental balance. In the third section I mentioned the relationship of purposes of Islamic law (sharia) with preserving the environmental balance. The fourth section in which I referred to the most important Fiqh rules and its applications upon the environmental balance. As for the last section I highlighted the most important means of assessing environmental imbalance in Islam.

Keywords: Islamic Law, Fiqh, Environmental Protection, Environmental Balance, Islam and Environment.

المقدمة

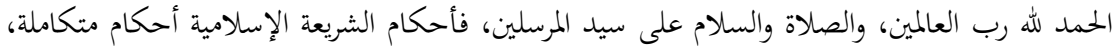

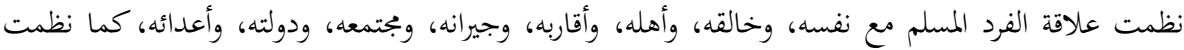

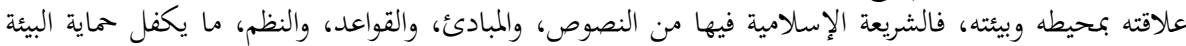
وتوازها، وإيجاد الحلول الممكنة للمشاكل البيئية الحادثة.

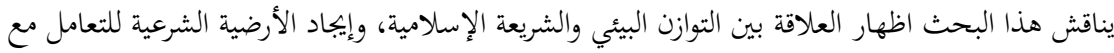

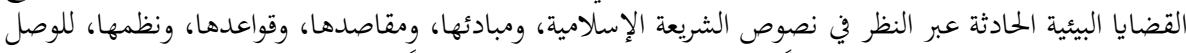
إلى تصور إسلامي يخدم المسلين عموماً، والعاملين في المجال البيئي خصوصاً. وكان لاختيار الموضوع أسباب كثيرة منها:

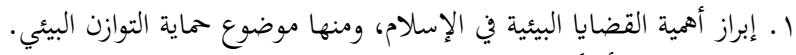

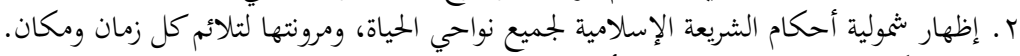

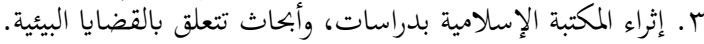

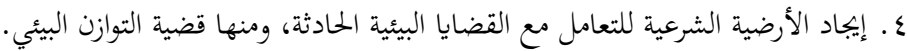

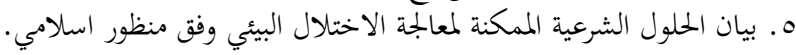

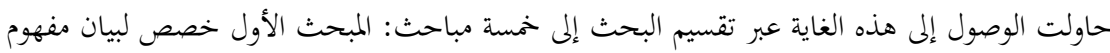

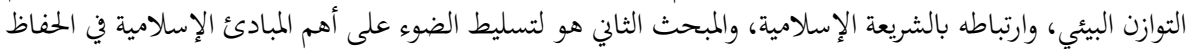

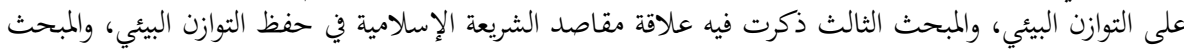

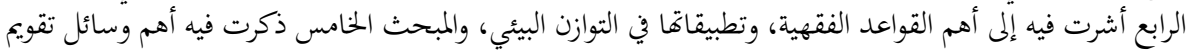
الاختلال البيئي في الإسلام.

$$
\text { 1 ا. المبحث الأول: الثوازن البيئي: تعريفه، عناصره، وارتباطه بالشريعة الإسلامي }
$$

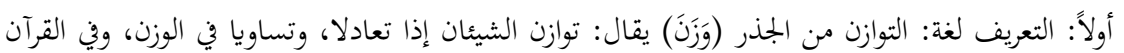

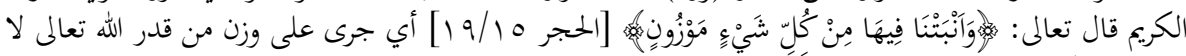

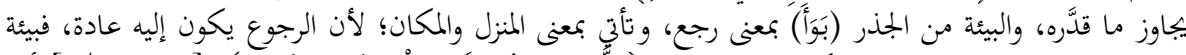

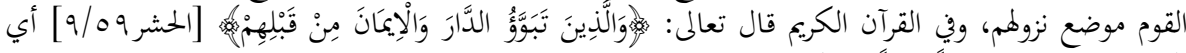

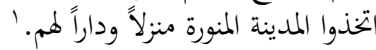
ثانياً: التعريف اصطلاحاً: لم يرد تعريف مصطلح البيئة هذذا اللفظ في كتب التراث الإسلامي كونه من

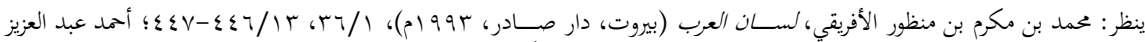

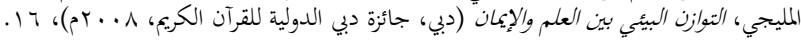




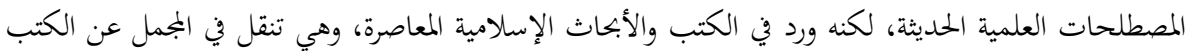

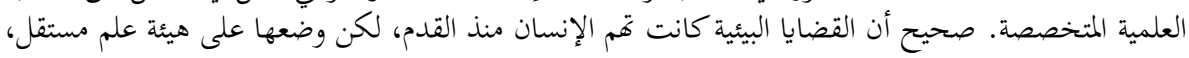

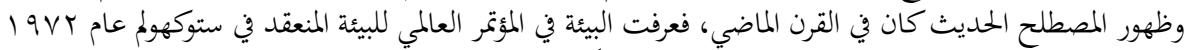

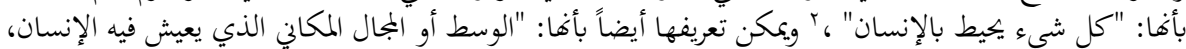

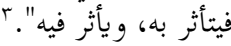

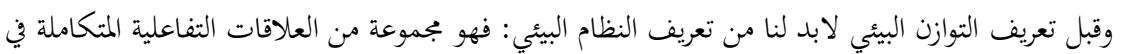

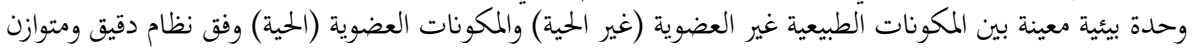

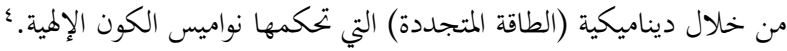

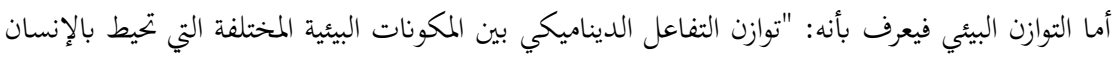

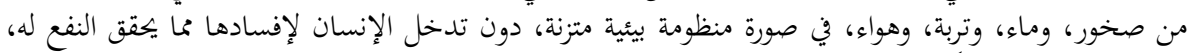

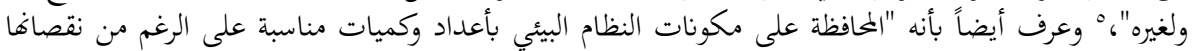

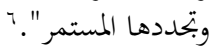

ومن خلال التعاريف السابقة يمكننا أن نلاحظ بجموعة من النقاط:

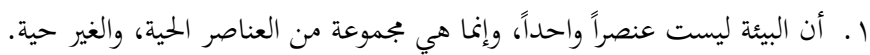

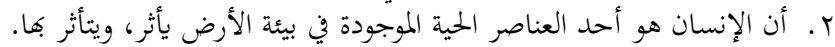

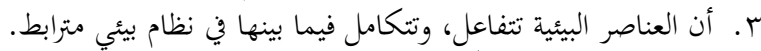

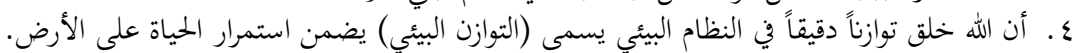

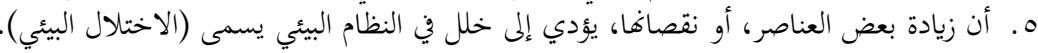
ا. Y. المطلب الثاني: عناصر البيئة

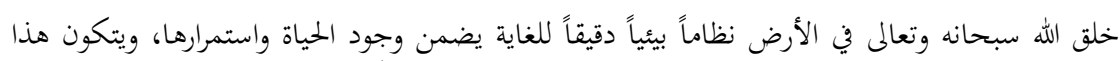

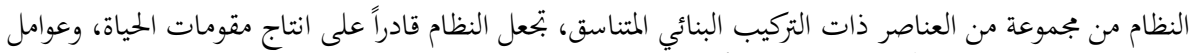

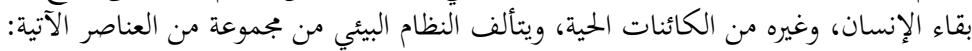

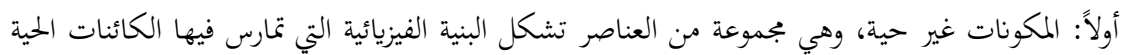

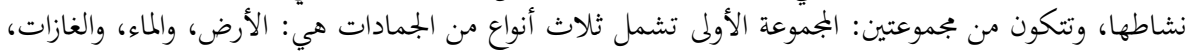

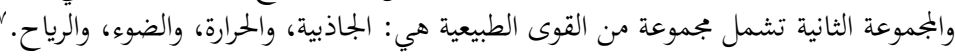

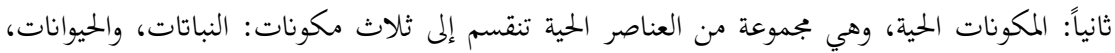

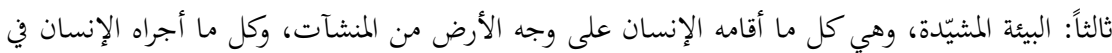

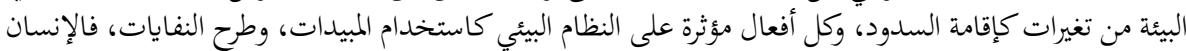

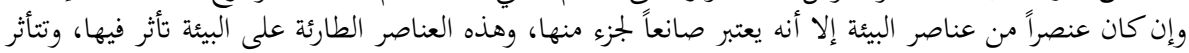

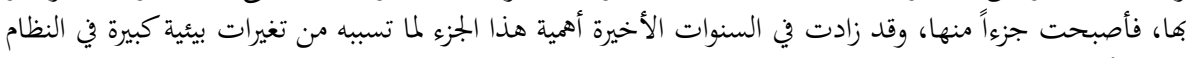

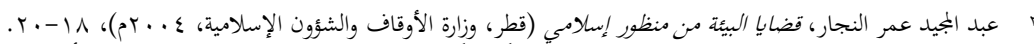

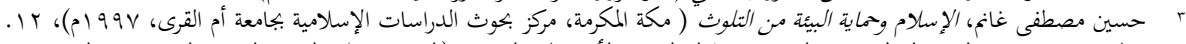

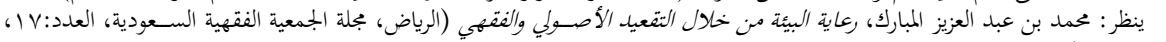

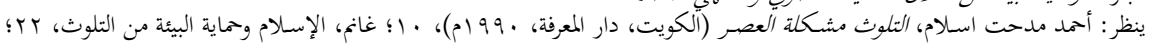

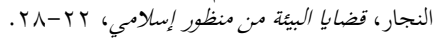

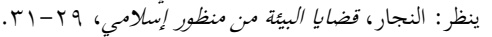

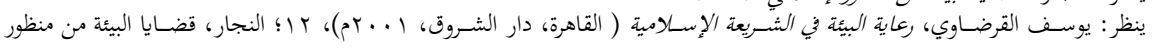


ا ـ r. المطلب الثالث: ارتباط التوازن البيئي بالشريعة الإسلامية

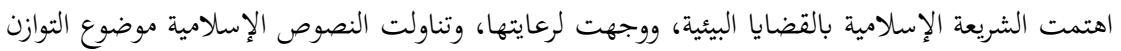

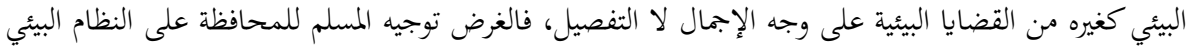

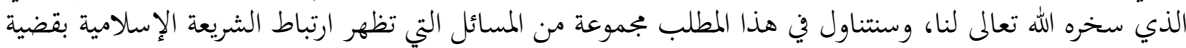
التوازن البيئي. أولاً: ارتباط التوازن البيئي بالإيمان.

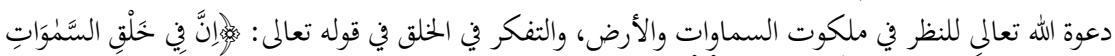

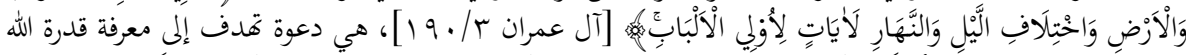

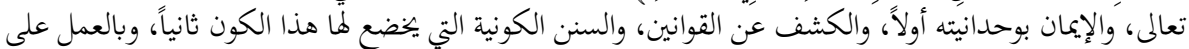

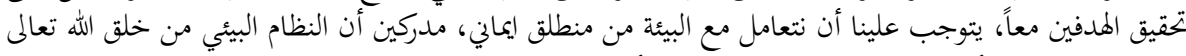

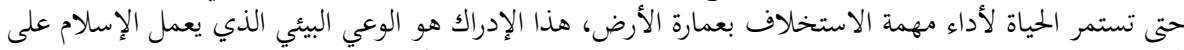

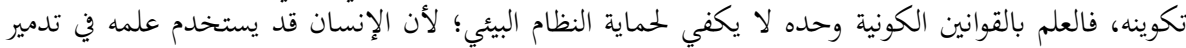

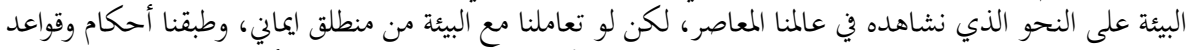

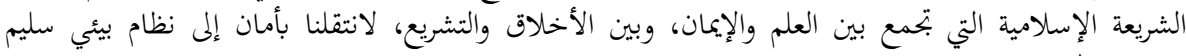
ومتوازن.

ثانياً: ارتباط التوازن البيئي بمفهوم مقصد الخلق.

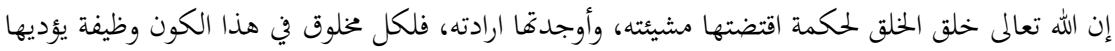

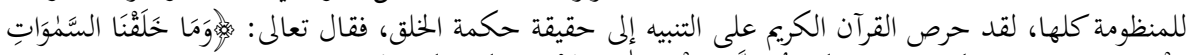

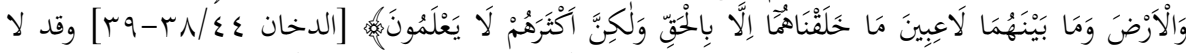

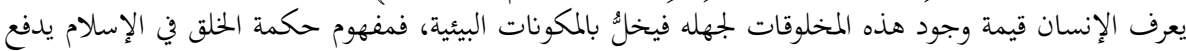
المسلم للحفاظ على المكونات البيئة.

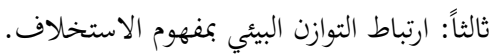

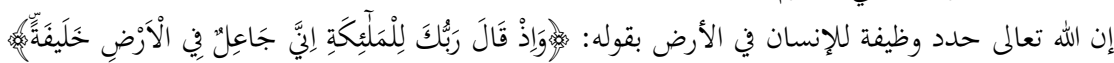

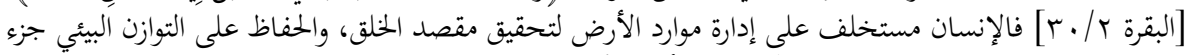

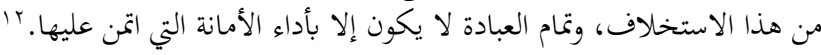
رابعاً: ارتباط التوازن البيئي بمفهوم التسخير.

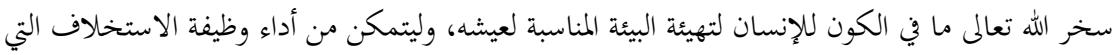

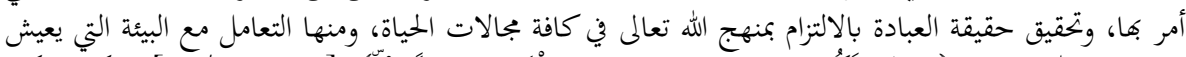

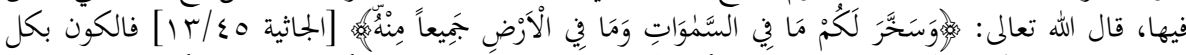

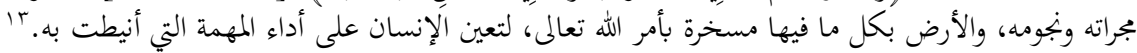

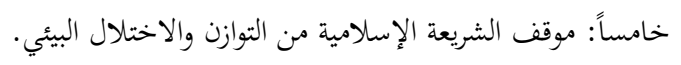

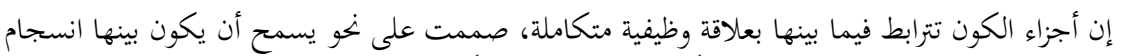

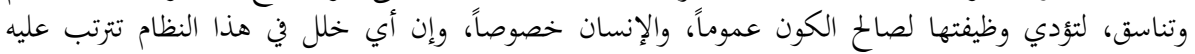

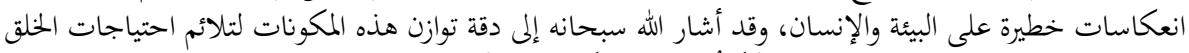

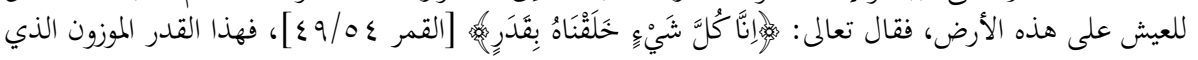


خلقه الله سبحانه وتعالى، فلو زاد عن حده، أو نقص، لاختل التوازن البيئي، وذاق الخلق نتاج فساد أعمالهم حتى

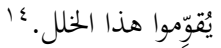

Y ب. المبحث الثاني: مبادئ إسلامية للحفاظ على التوازن البيئي

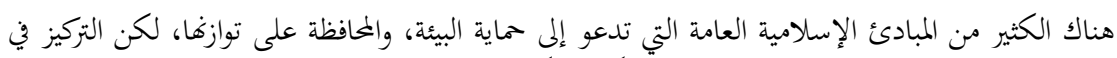

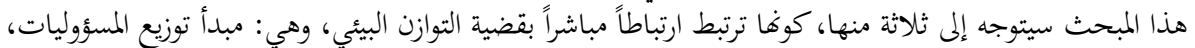
ومبدأ الحماية، ومبدأ التنمية.

\section{r. أ. ا. المطلب الأول: مبدأ توزيع المسؤوليات في الإسلام}

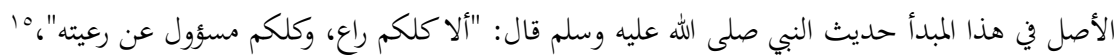

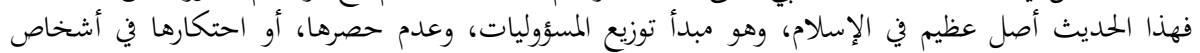

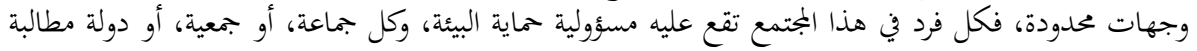
بحفظ التوازن البيئي ضمن نطاق مسؤ فودونياتما.

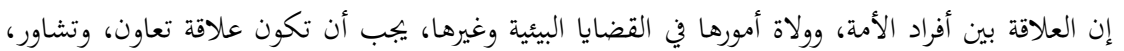

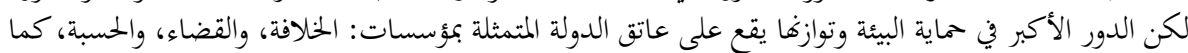

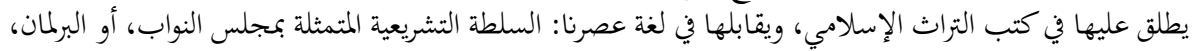

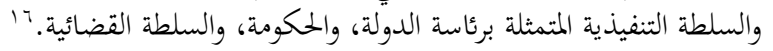

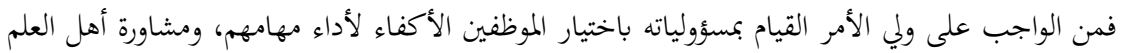

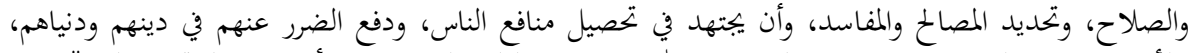

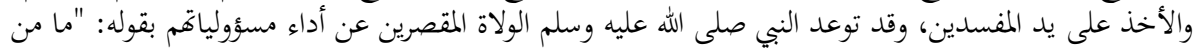

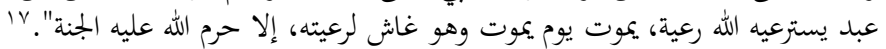

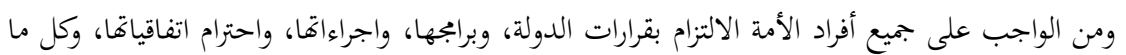

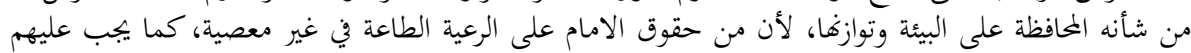

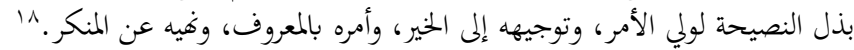

$$
\text { r. Y. r. المطلب الثاني: مبدأ الحماية في الإسلام }
$$

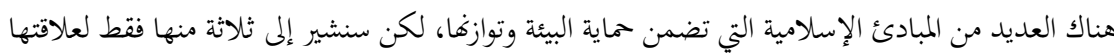

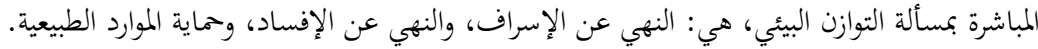

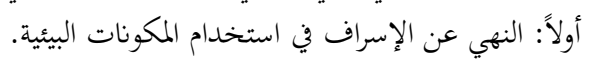

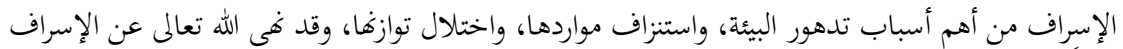

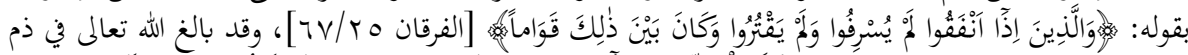

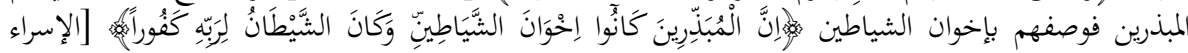

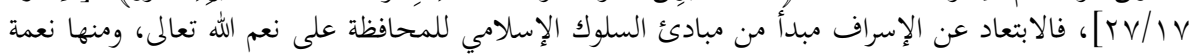
التوازن البيئي.

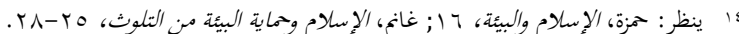

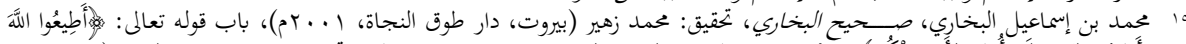

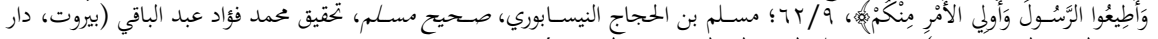

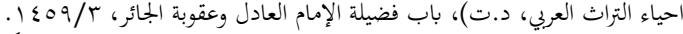

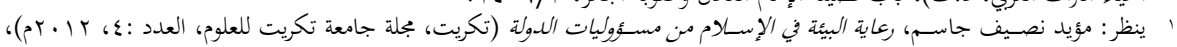
. T. T/19

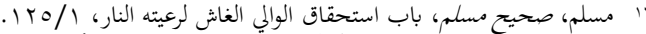

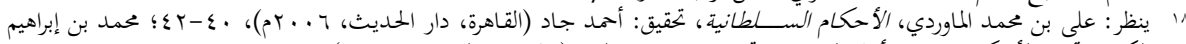

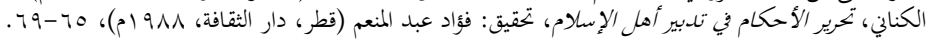




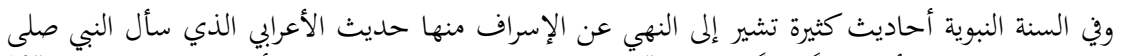

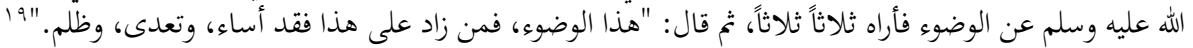

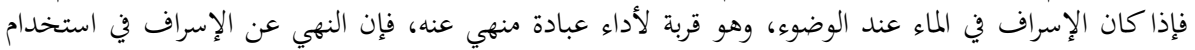

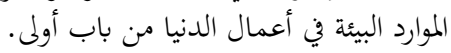
ثانياً: النهي عن افساد المكونات البيئية.

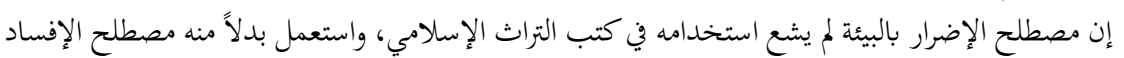

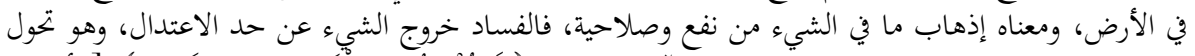

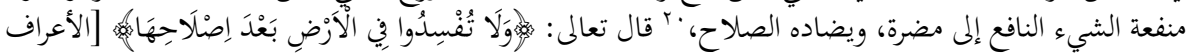

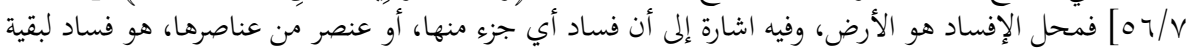

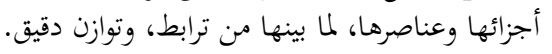

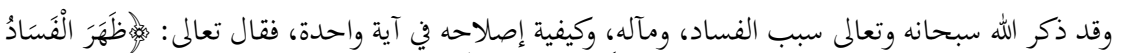

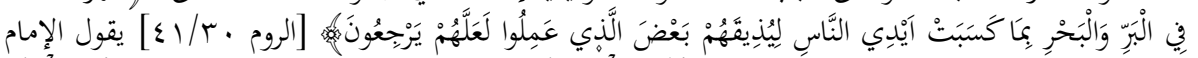

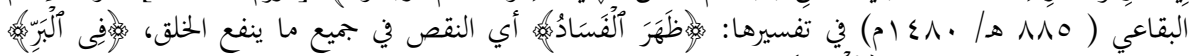

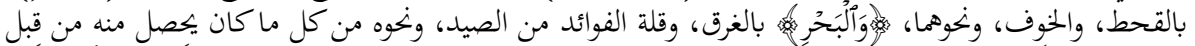

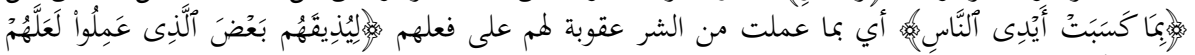

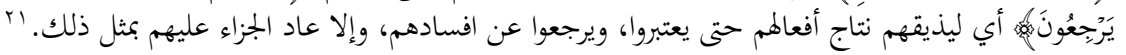

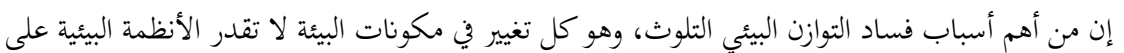

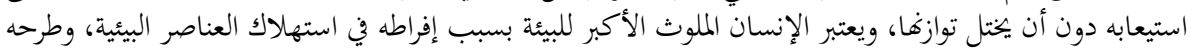

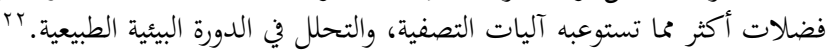

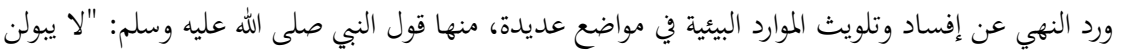

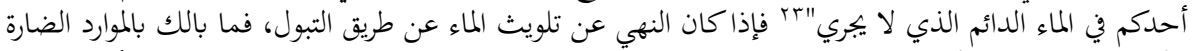

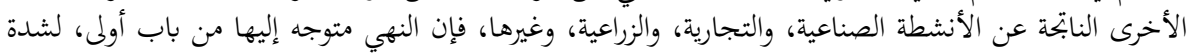

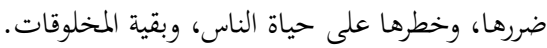

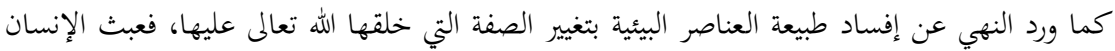

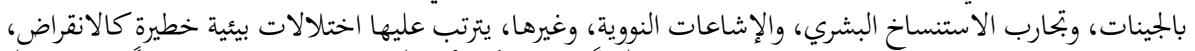

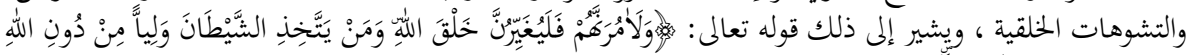

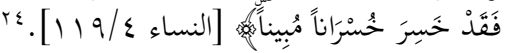
ثالثاً: حماية الموارد الطبيعية.

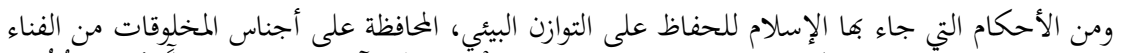

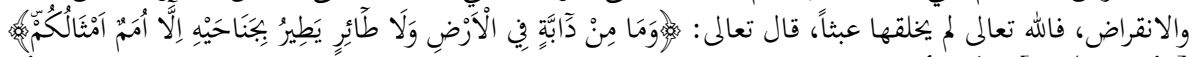

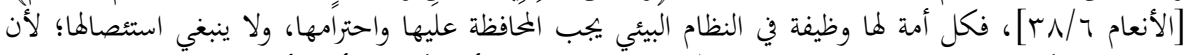

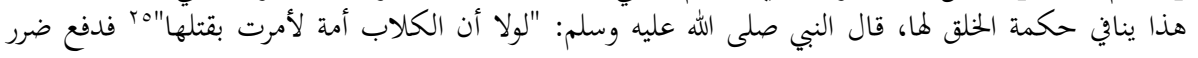

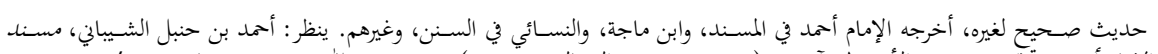

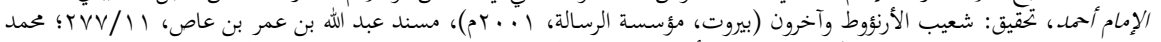

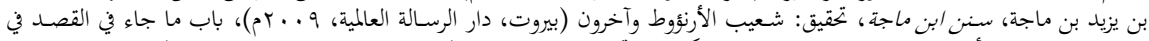

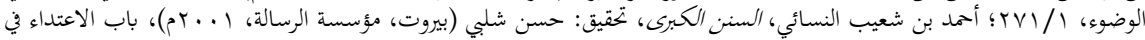

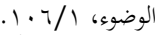

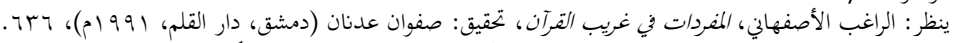

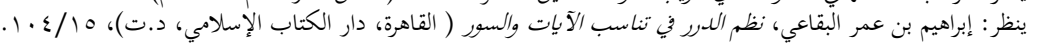

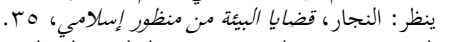

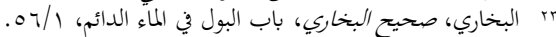

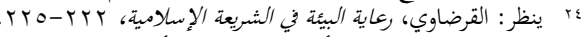

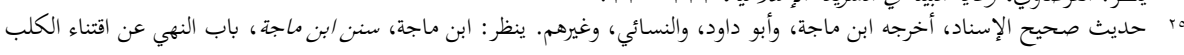




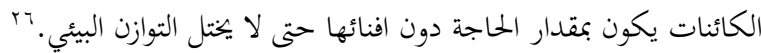

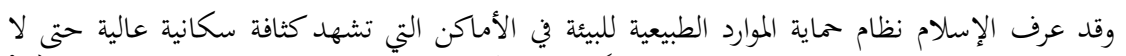

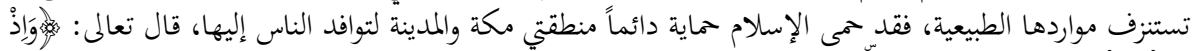

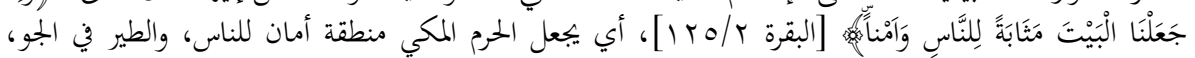

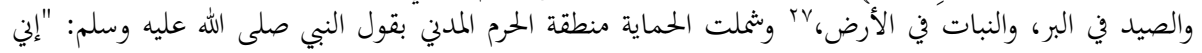

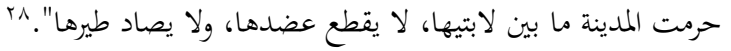

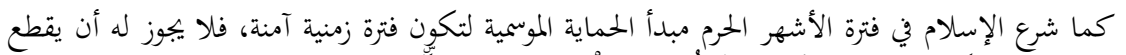

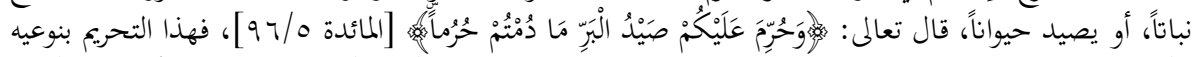

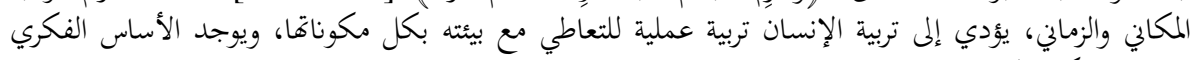
والعملي لفكرة المحميات الطبيعية.

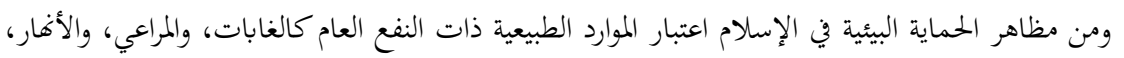

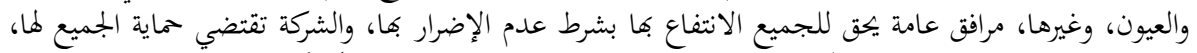

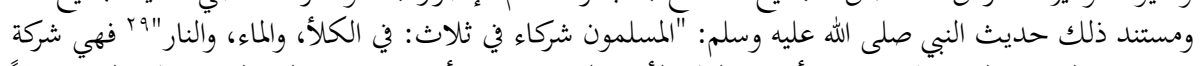

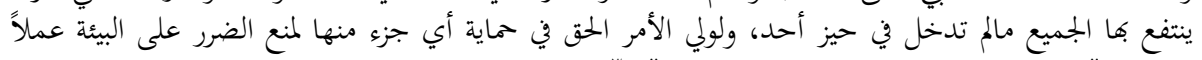

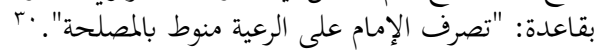

Y. Y. ا. المطلب الثالث: مبدأ التنمية في الإسلام

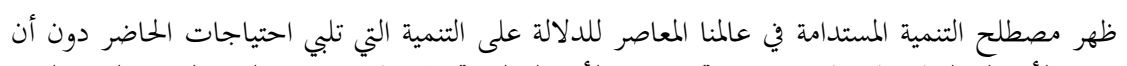

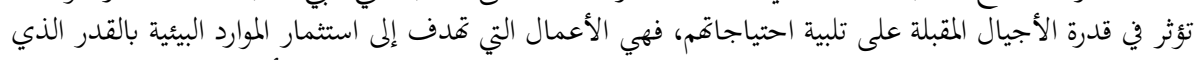

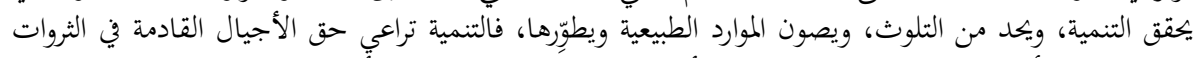

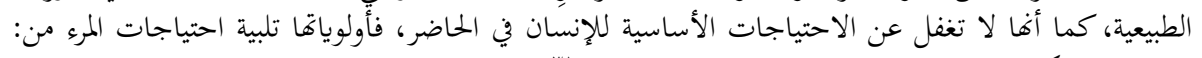

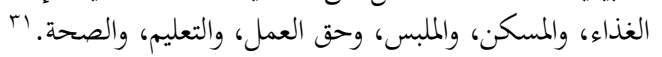

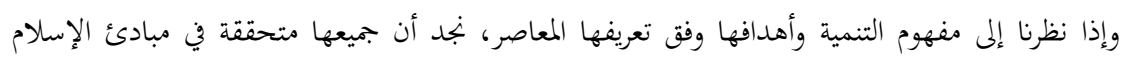

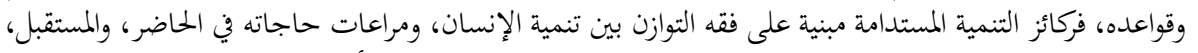

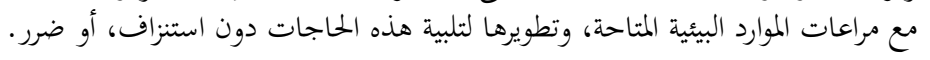

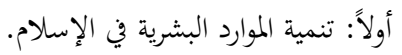

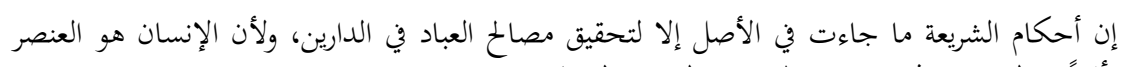
الأكثر تأثيراً في البيئة وتوازفها، سنشير إلى عنائ في الاصل الشريعة الإسلامية بتنميته:

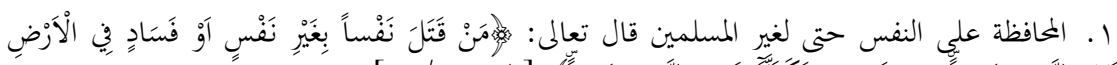

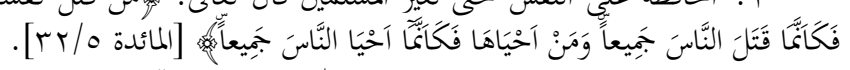

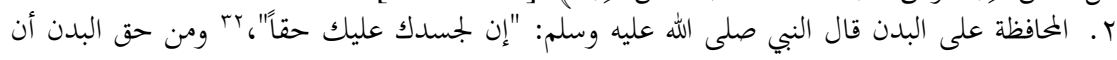

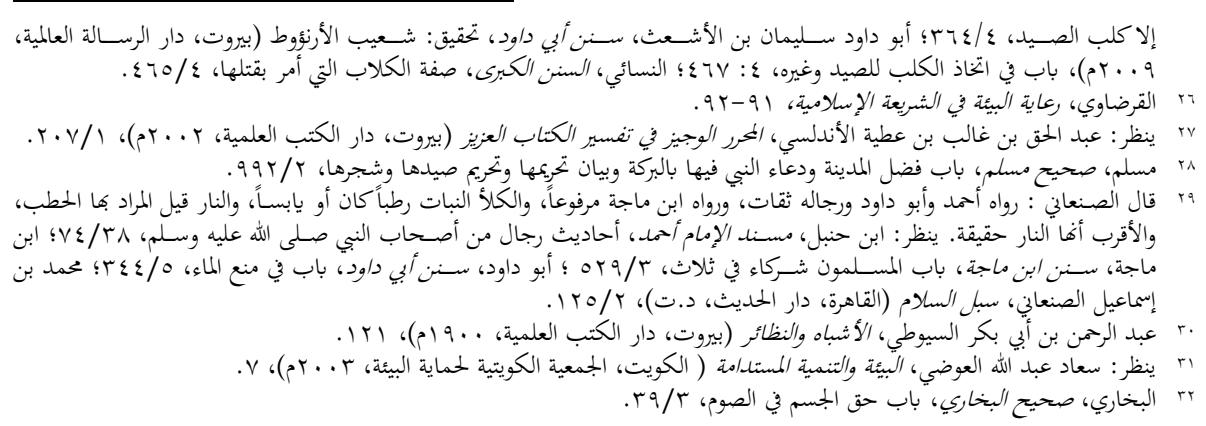




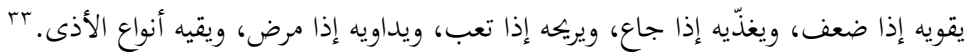

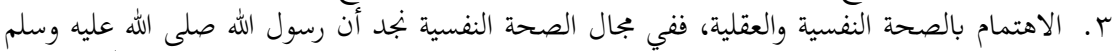

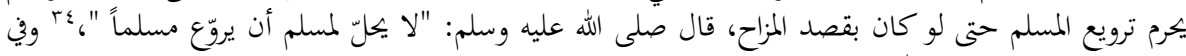

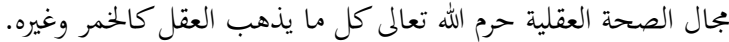

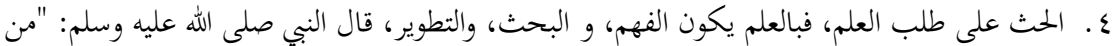

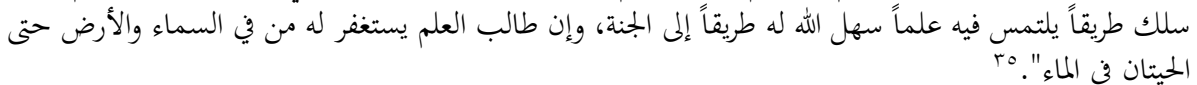

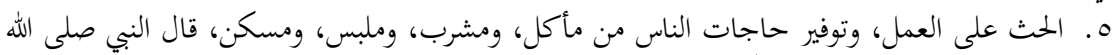

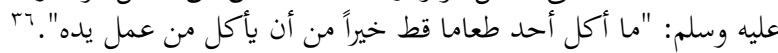

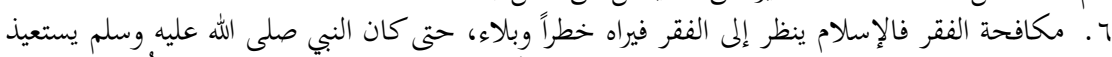

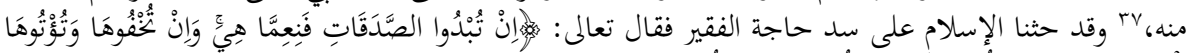

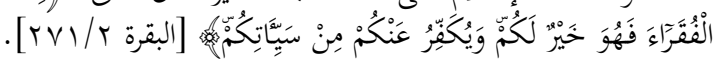
ثانياً: تنمية الموارد الطبيعية في الإسلام.

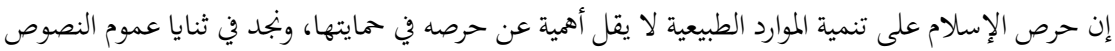

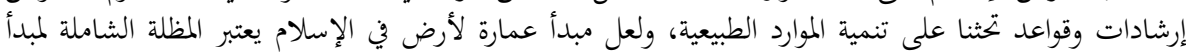

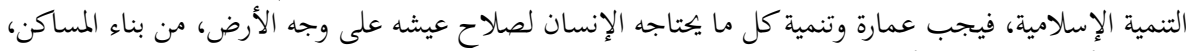

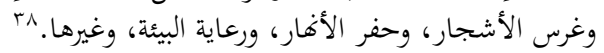

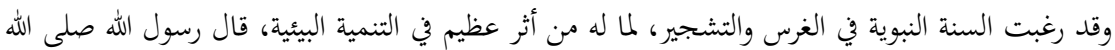

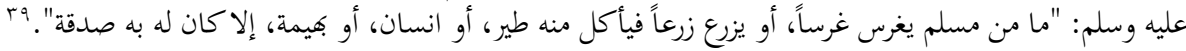

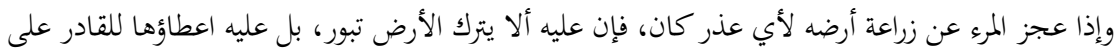

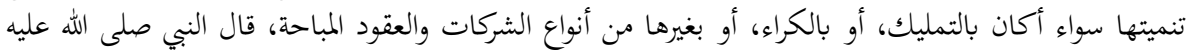

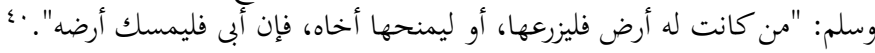

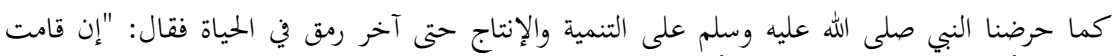

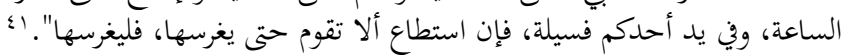

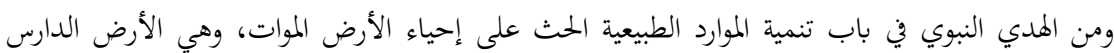

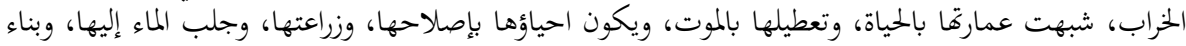

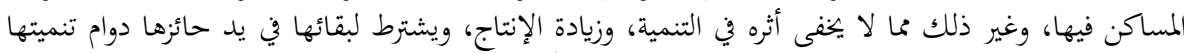

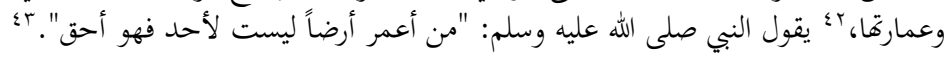

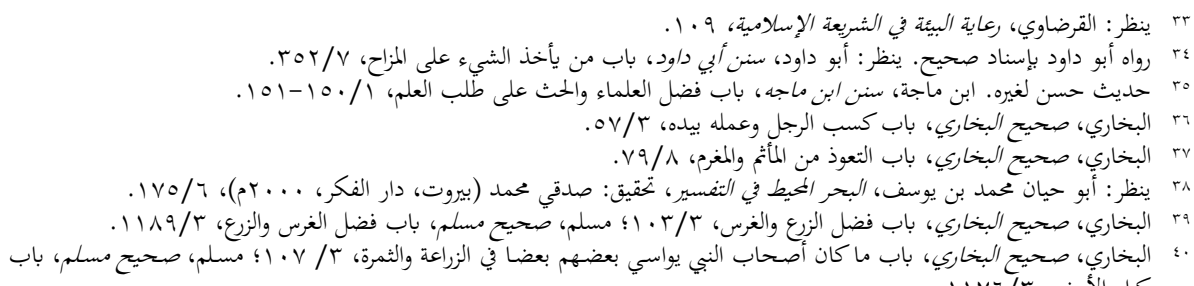

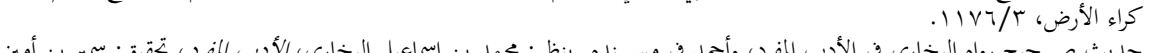

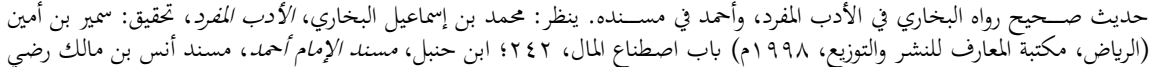

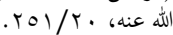


r. المبحث الثالث: مقاصد الشريعة الإسلامية في الحفاظ على التوازن البيئي

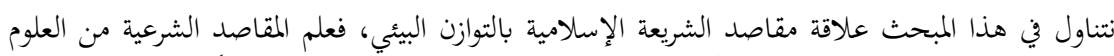

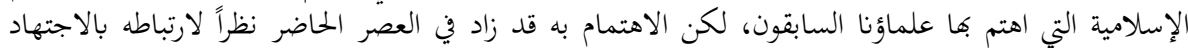

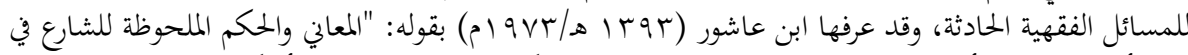

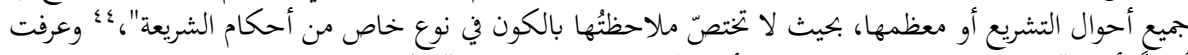

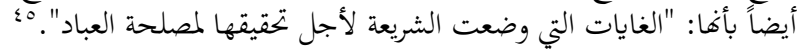

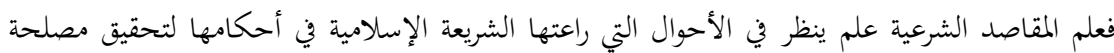

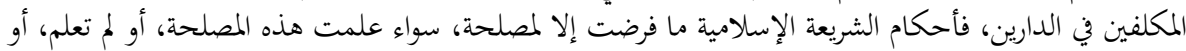

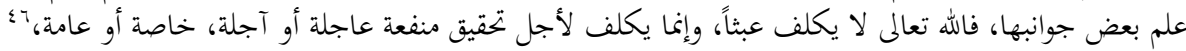

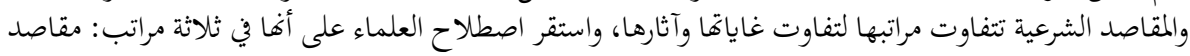

ضرورية، ومقاصد حاجية، ومقاصد تحسينية.

ب. أ ا ـ المطلب الأول: الضروريات في التوازن البيئي

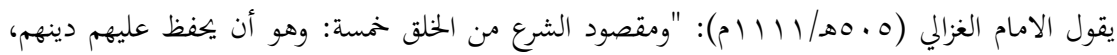

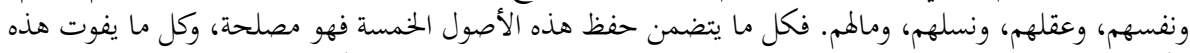

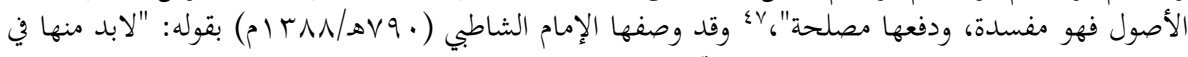

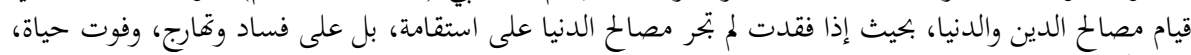

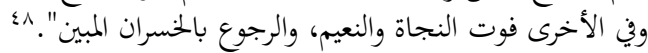

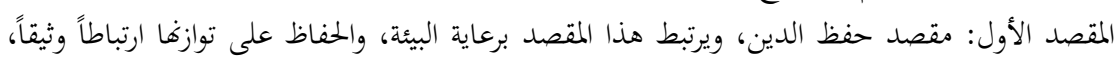

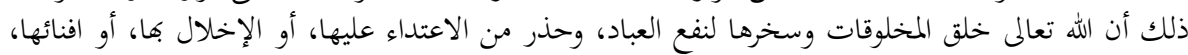

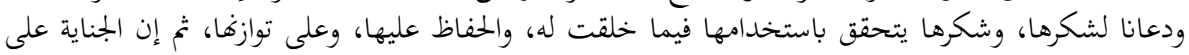

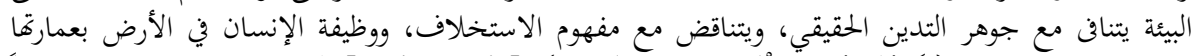

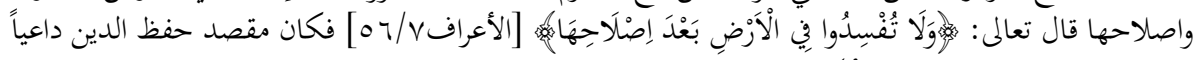
إلى رعاية البيئة، والعناية بتوازها.

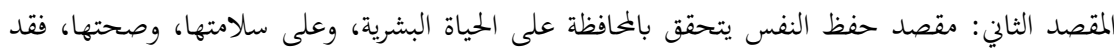

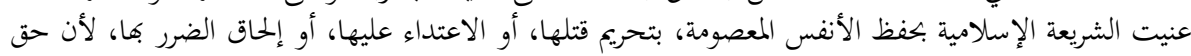

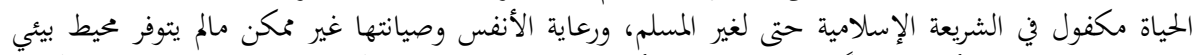

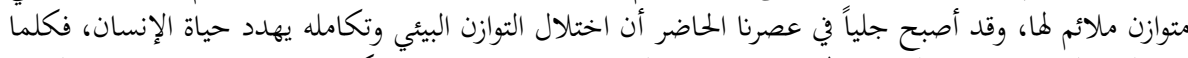

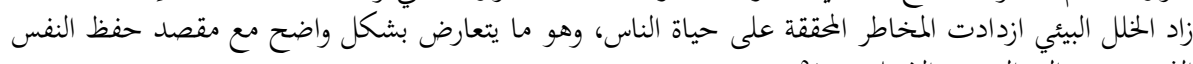

الذي دعت إليه الشريعة الإسلامية. •

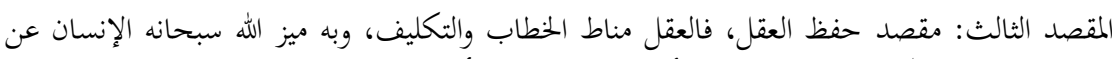

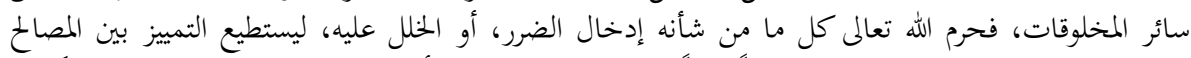

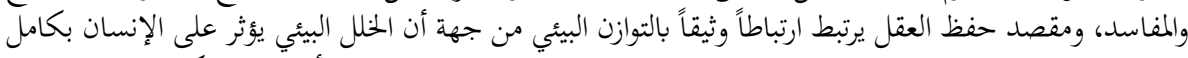

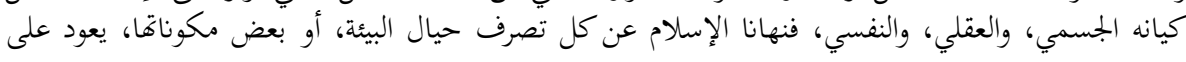

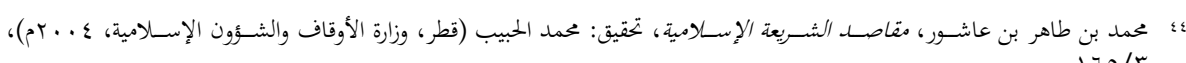

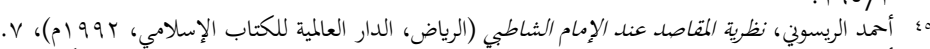

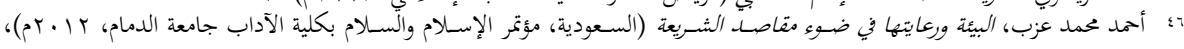
VO-Vr

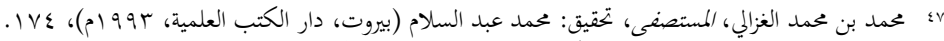

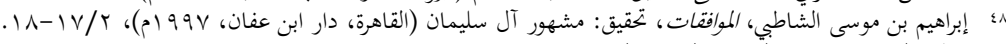

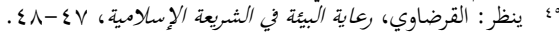

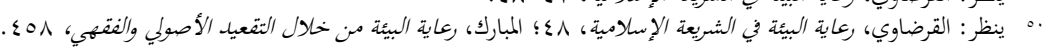


الإنسان بالضرر، والآفات في عقله، وتفكيره، فحفظ التوازن البيئي يحقق هذا المقصد، ويحفظ سلامة العقل من هذا الجانب. الإنسان بالضران

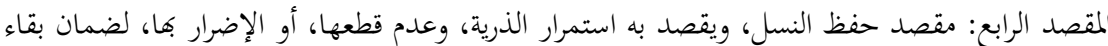

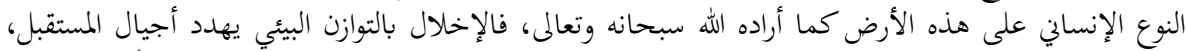

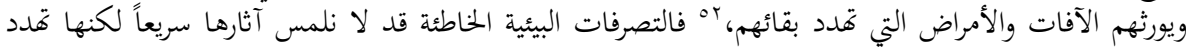

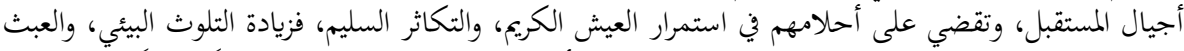

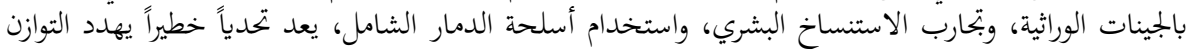

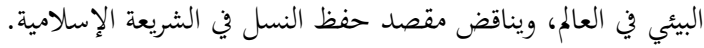

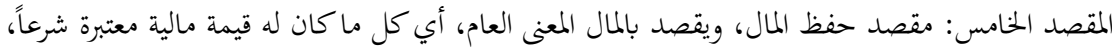

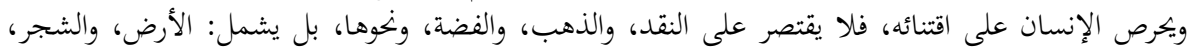

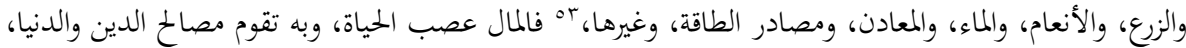

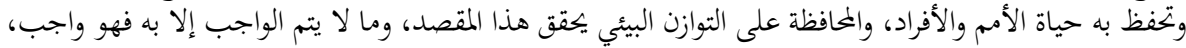

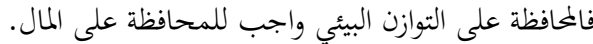

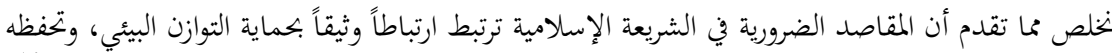

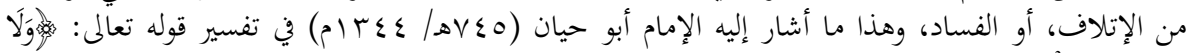

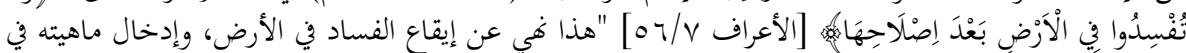

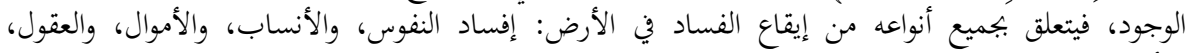

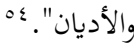

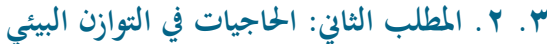

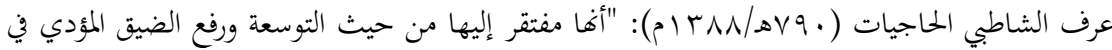

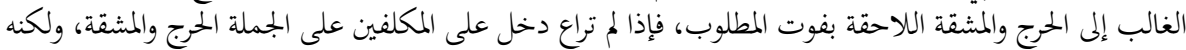

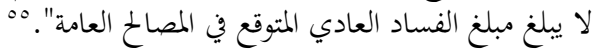

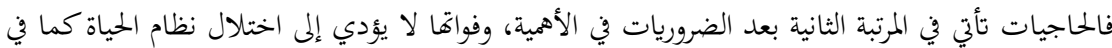

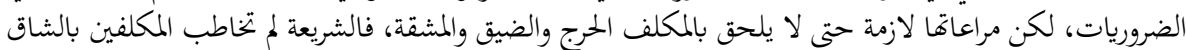

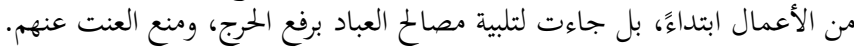

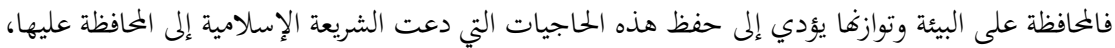

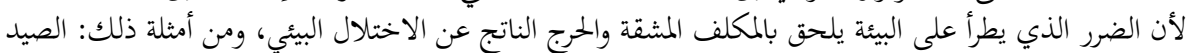

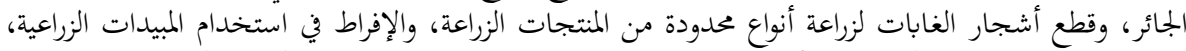

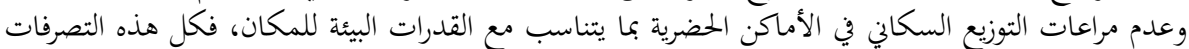

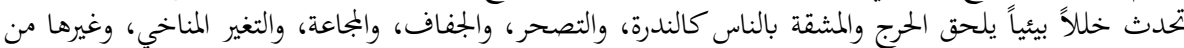
آثار الاختلال البيئي.

\section{ب. ب. ب. المطلب الثالث: التحسينات في الثوازن البيئي}

تعرف التحسينات بأها: "الأخذ بما يليق من محاسن العادات، وبتحب المدنسات التي تأنفها العقول

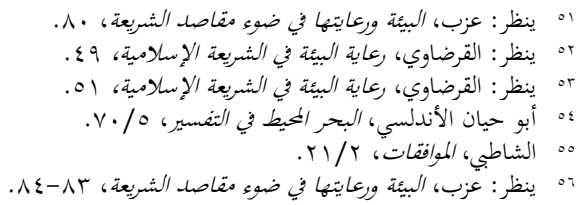




$$
\text { الراجحات، ويجمع ذلك قسم مكارم الأخلاق". }
$$

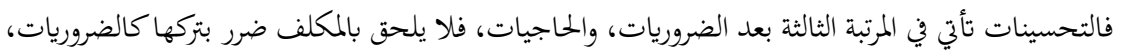

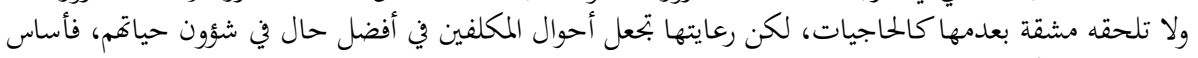

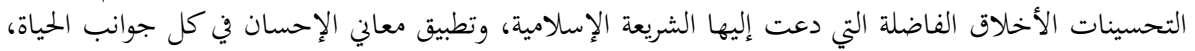

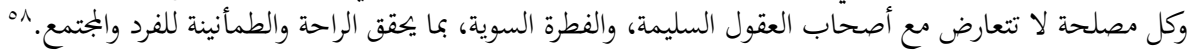

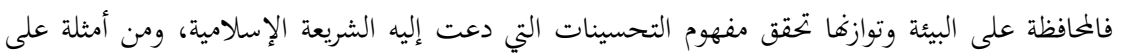

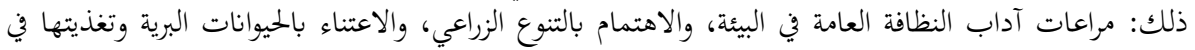

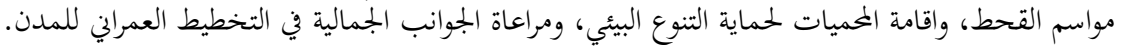

$$
\text { ع ـ المبحث الرابع: القواعد الفقهية وتطبيقاتما في التوازن البيئي }
$$

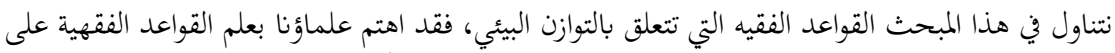

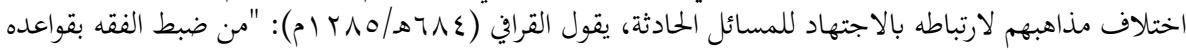

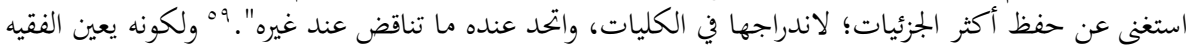

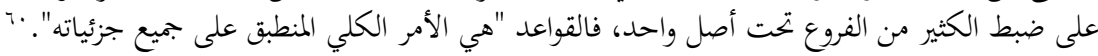

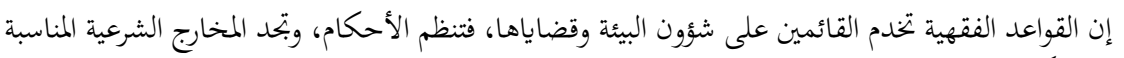

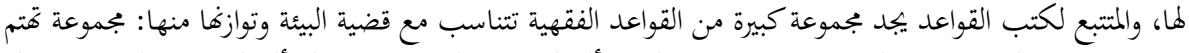

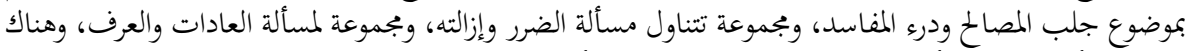

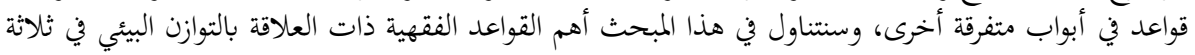
مطالب.

\section{ع. ـ ـ المطلب الأول: قواعد مراعات المصاح ودرء المفاسد}

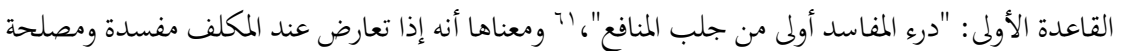

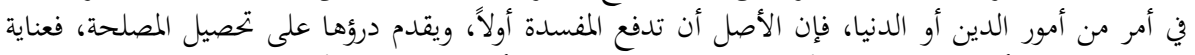

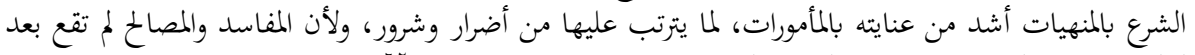

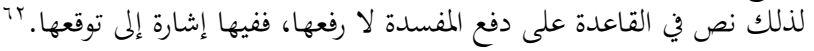

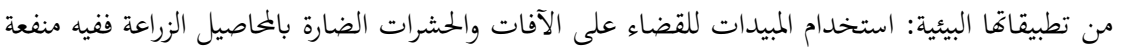

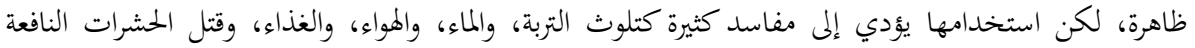

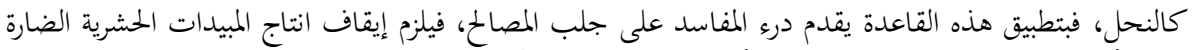

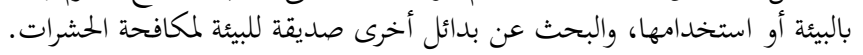

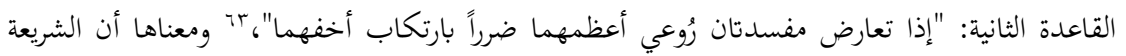

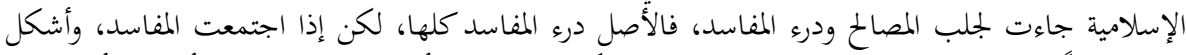

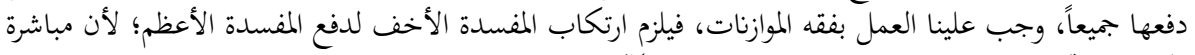

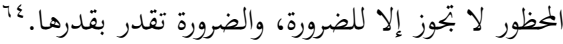

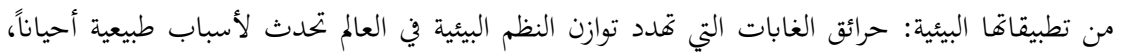

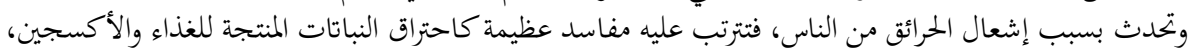

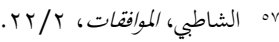

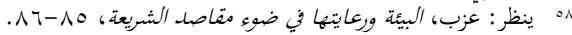

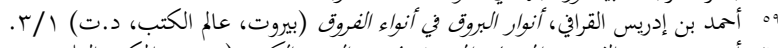

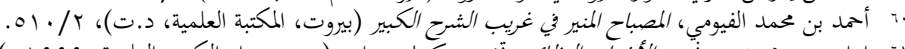

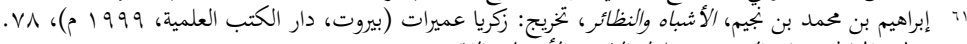

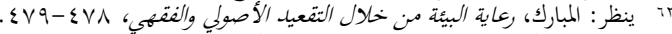

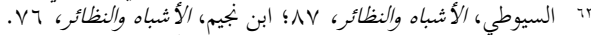

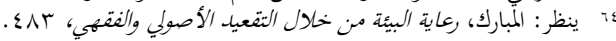




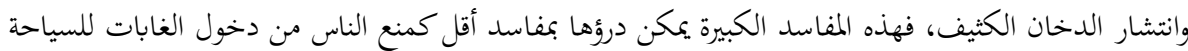

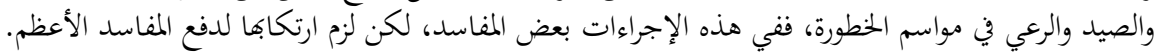

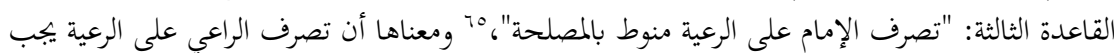

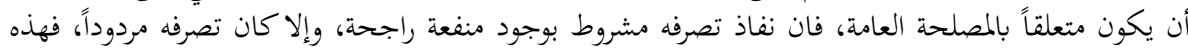

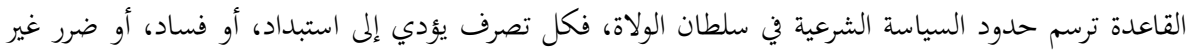

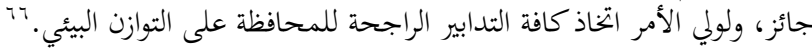

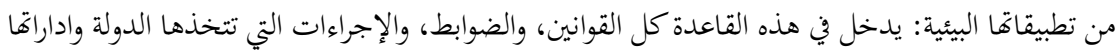

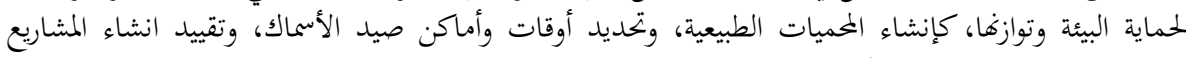
الصناعية والاستثمارية بشرط المحافظة على البيئة.

ع. Y. المطلب الثالي: قواعد الضرر وازالته

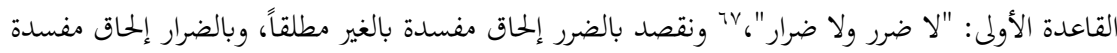

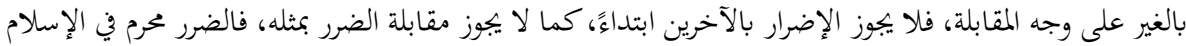
إلا بما أذن به الشرع كالعقوبات، والتعازير.

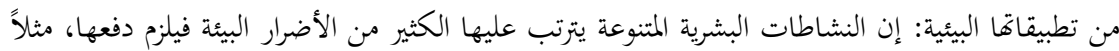

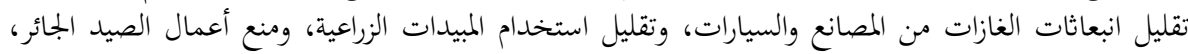
وغيرها من الأنشطة التي تؤثر على التوازن البيئي.

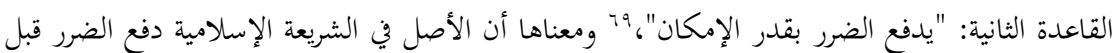

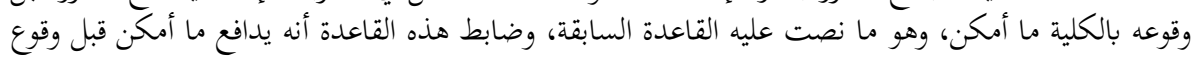

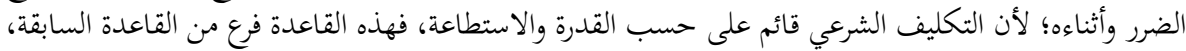

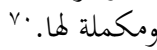

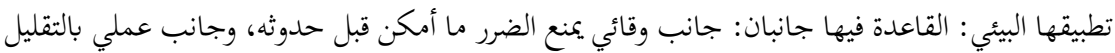

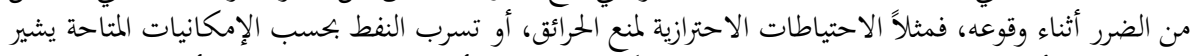

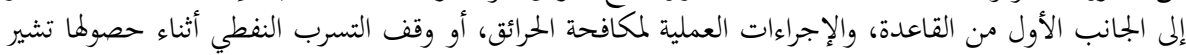

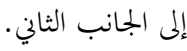

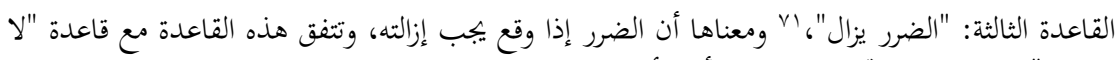

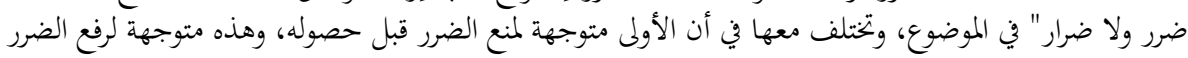
بعد وقوعه.

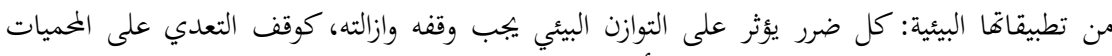

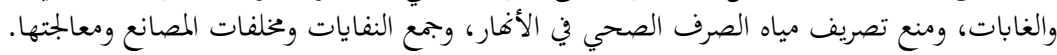

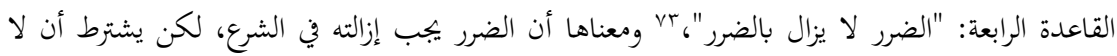

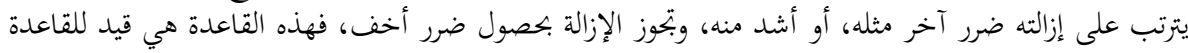

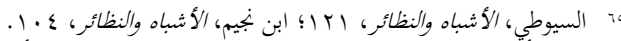

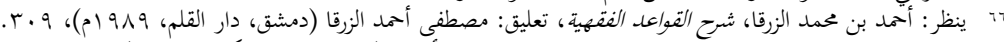

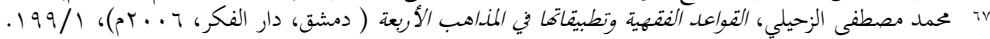

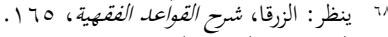

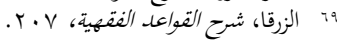

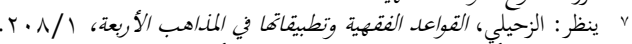

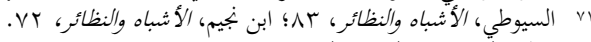

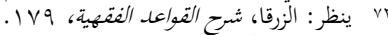

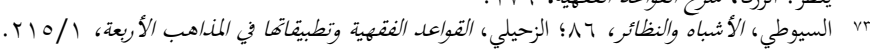


السابقة، ومكملة لها.

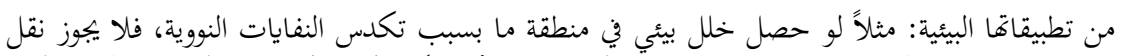

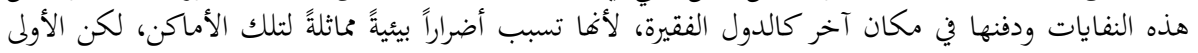

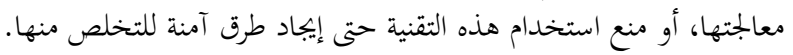

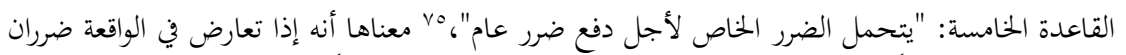

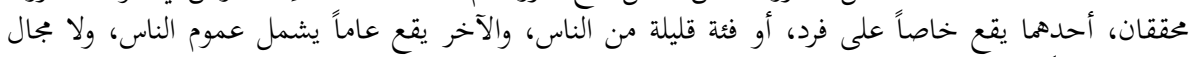

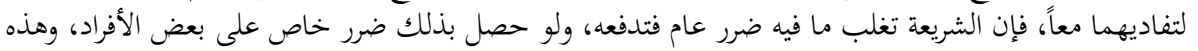

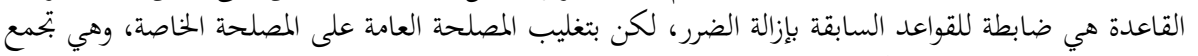
بين قواعد الضرر والمصلحة.

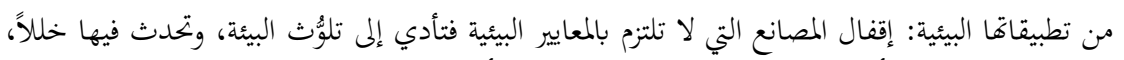

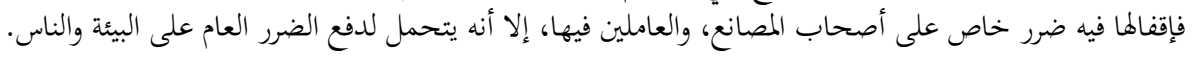

$$
\text { ع. ب. المطلب الثالث: قواعد العادات }
$$

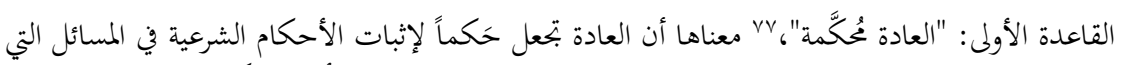

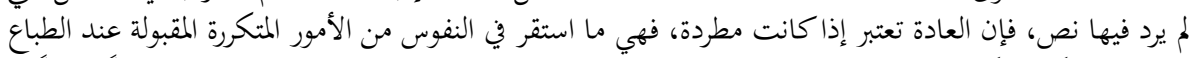

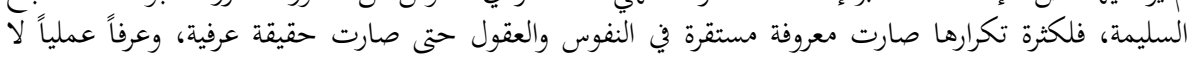

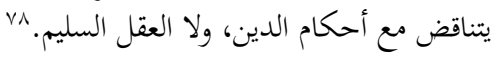

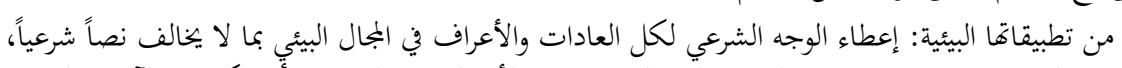

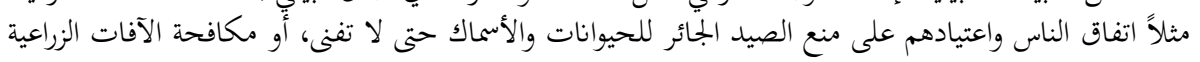
كالجراد في حال تمديدها للتنوع البيئي.

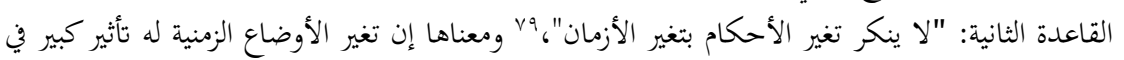

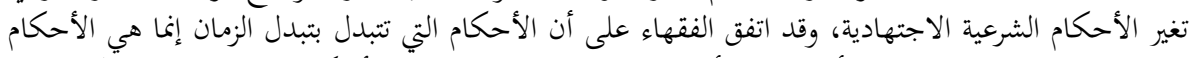

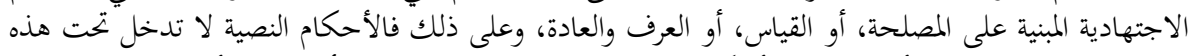

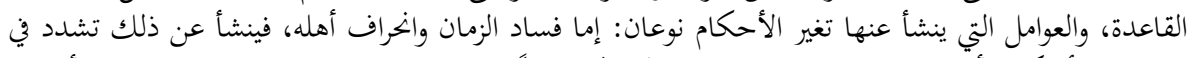

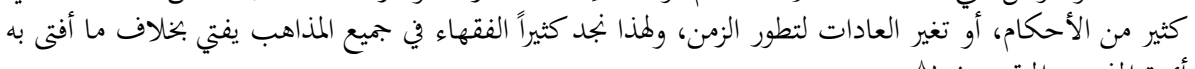

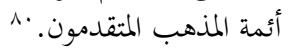

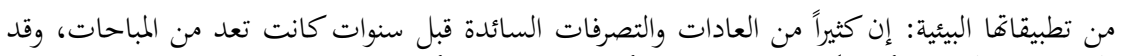

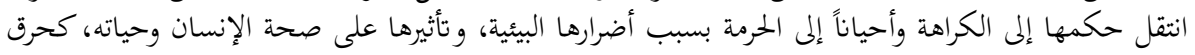

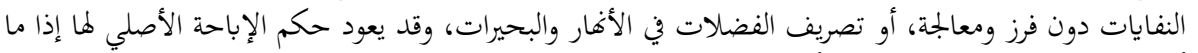
أخذت الاحتياطات اللازمة لتلافي أضرارها على البيئة والإنسان.

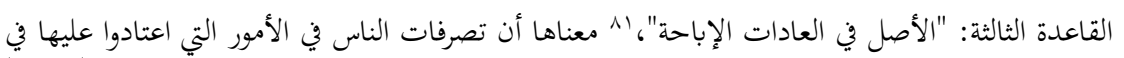

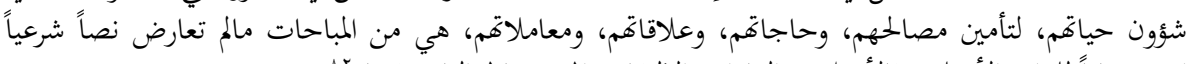

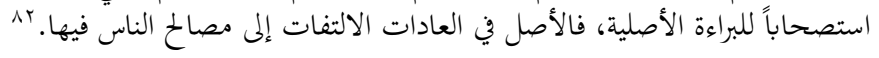

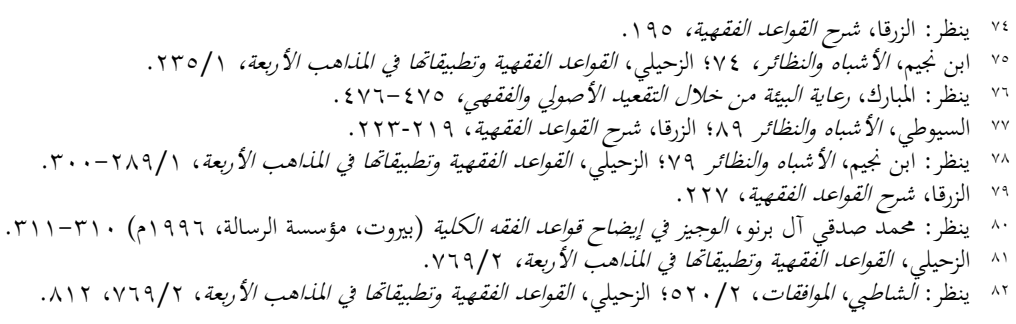




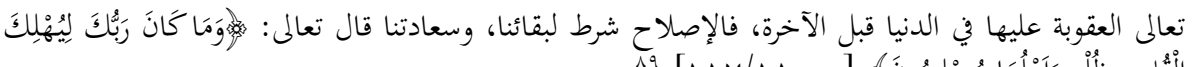

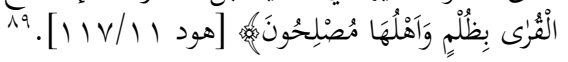

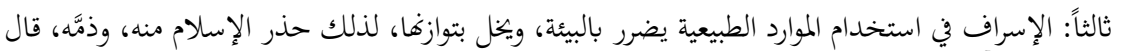

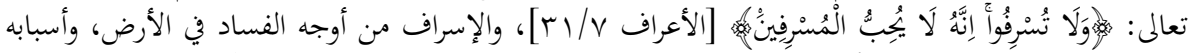

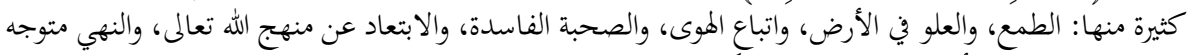

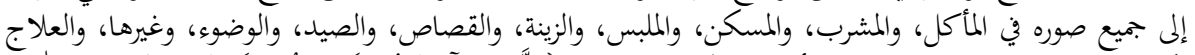

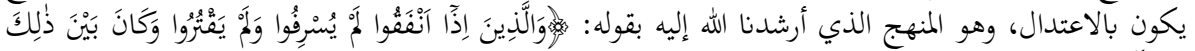

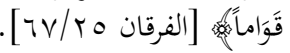

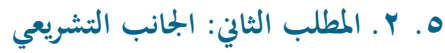

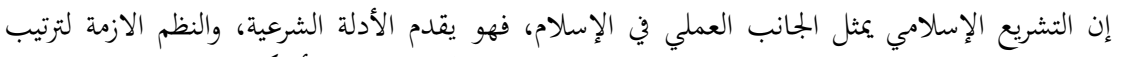

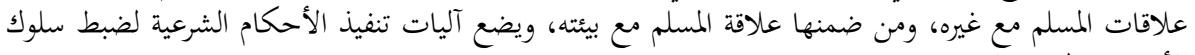

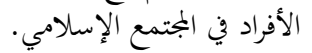

أولاً: دور الأدلة الشرعية الاجتهادية.

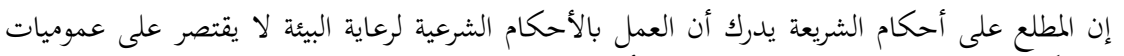

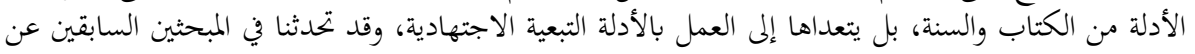

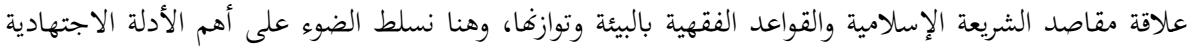

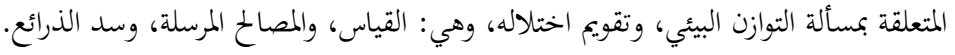

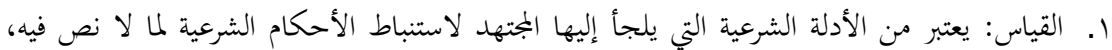

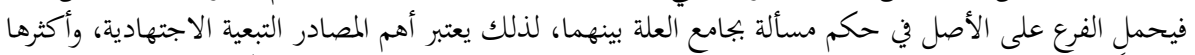

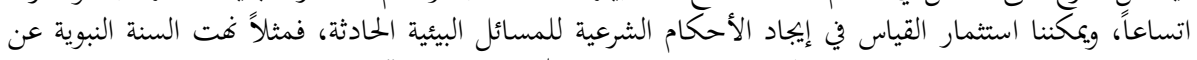

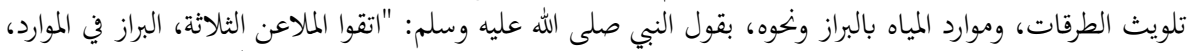

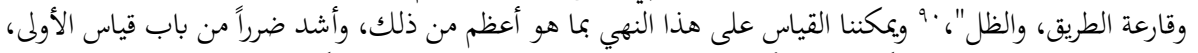

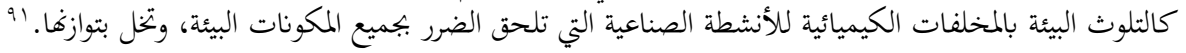

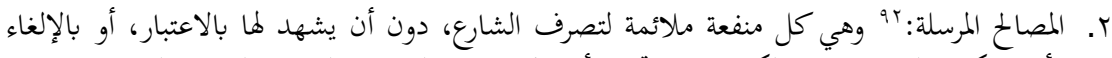

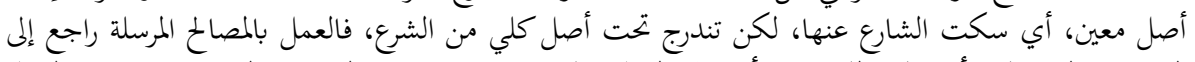

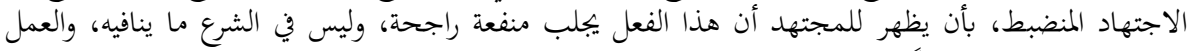

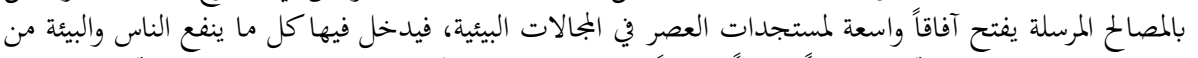

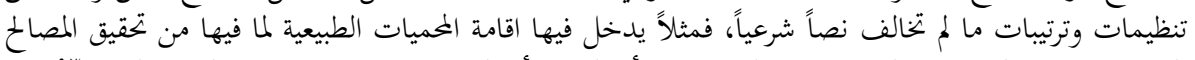

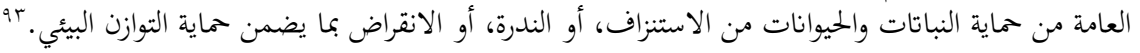

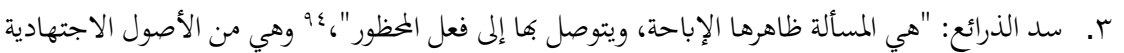

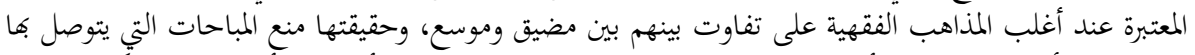

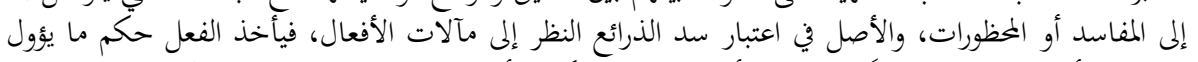

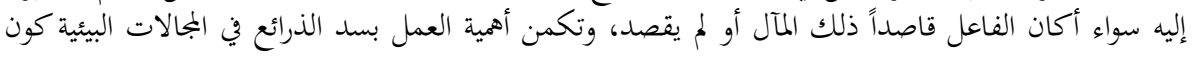

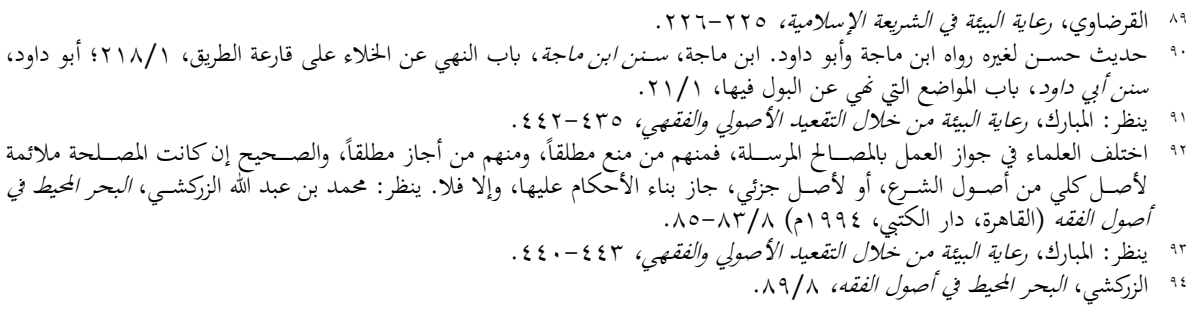




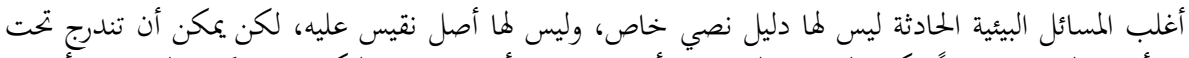

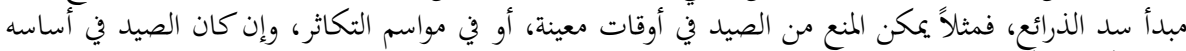

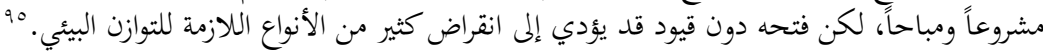
ثانياً: دور نظام العقوبات.

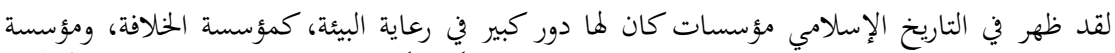

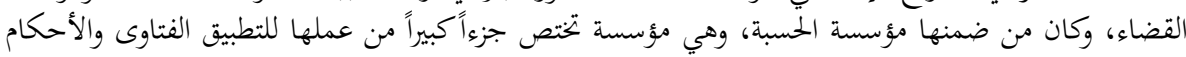

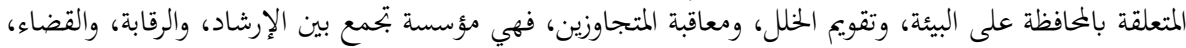

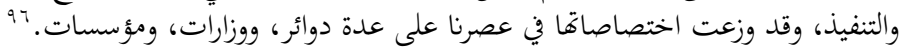

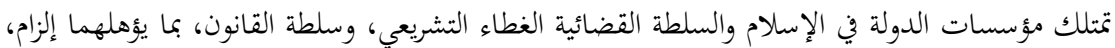

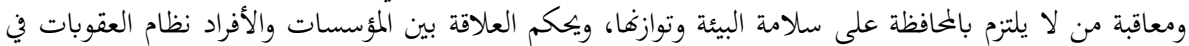

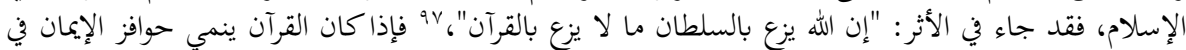

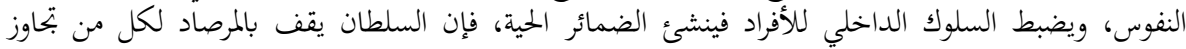

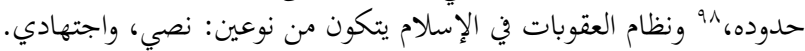

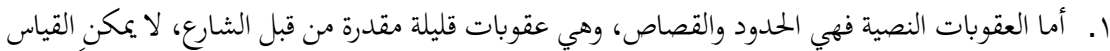

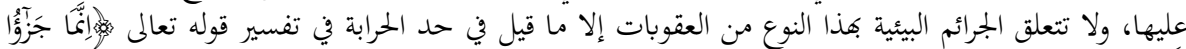

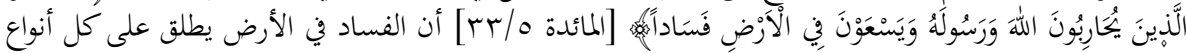

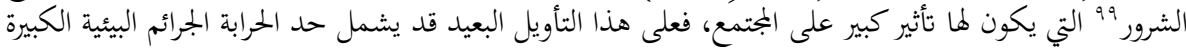

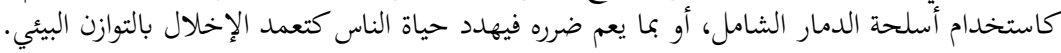

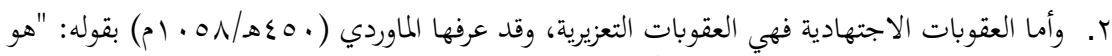

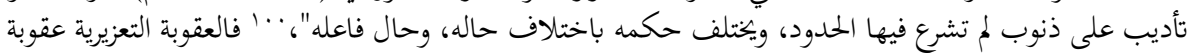

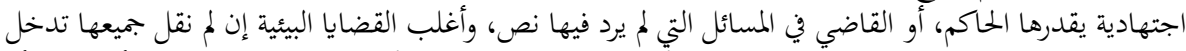

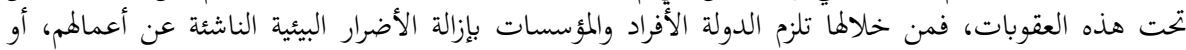
إصلاح الخلل الذي أحدثوه، أو دفع تعويضات مادية تستخدم في إعادم العادة التنمية البيئية.

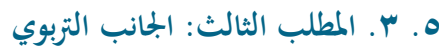

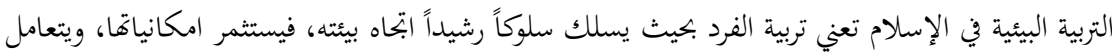

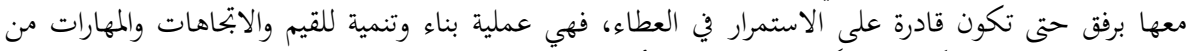

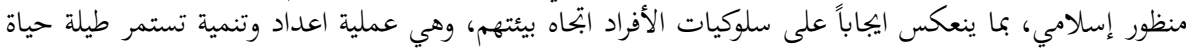

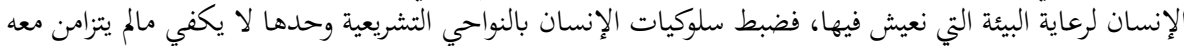

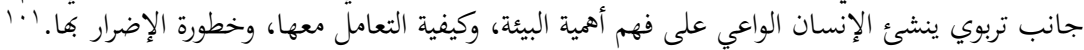

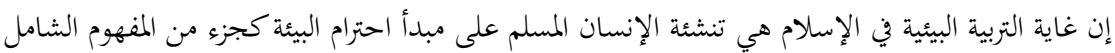

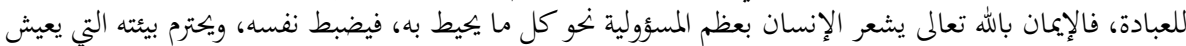

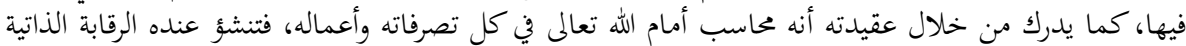

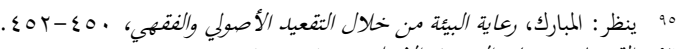

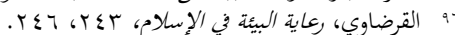

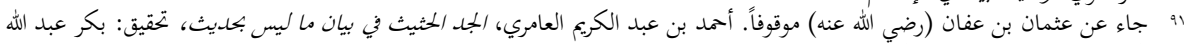

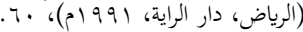

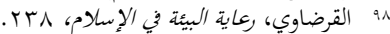

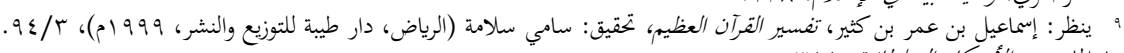

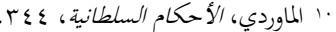

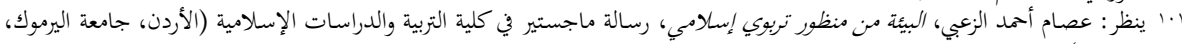




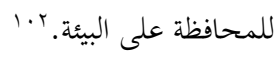

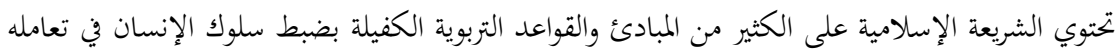

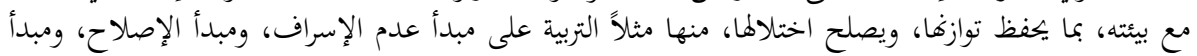

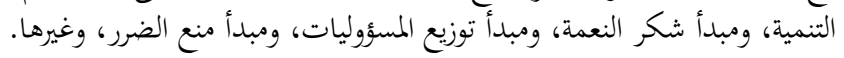

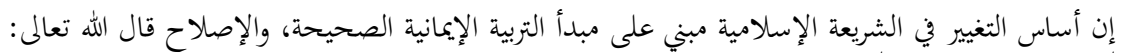

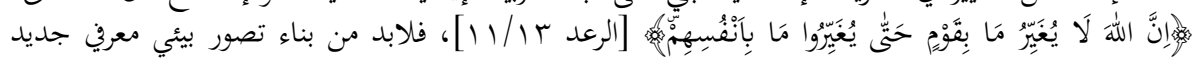

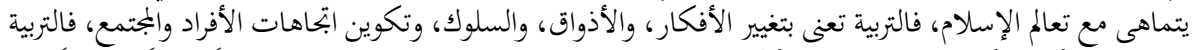

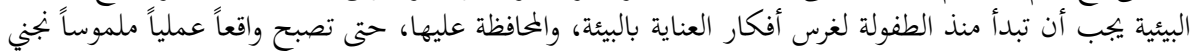

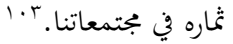

$$
\text { النتائج والمقترحات: }
$$

حاولت من خلال هذا البحث جمع أهم جوانب الموضوع، أرجو أن أكون قد وفقت لذلكن، ومن خلال البلات البحث توصلت إلى النتائج التالية:

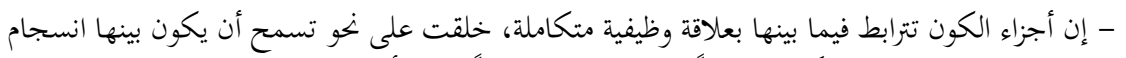

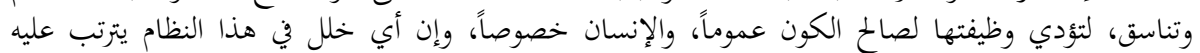
انعكاسات خطيرة على البيئة والإنسان.

- إن الشريعة الإسلامية بشمولما، وتكاملها، ومرونتها، قادرة على مواكبة قضائل الإنسان العصر الحادثة كقضية حماية التوازن البيئي. - اعتنت الشريعة الإسلامية بالتوازن البيئي، فأوجبت الحفاظ عليه، وحرمت الإخلال به، ووضعت الأحكام، والآليات اللازمة لذلك.

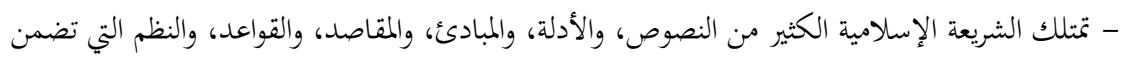
حفظ التوازن البيئي، وتقوم اختلاله.

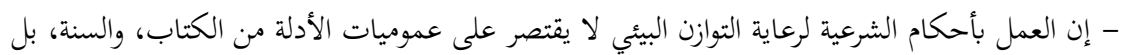

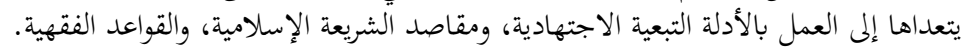

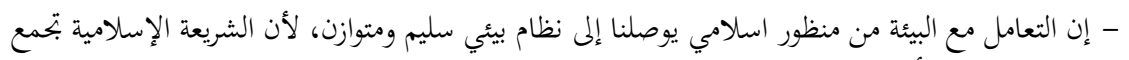
بين العلم والإيمان، وبين الأخلاق والتشريع.

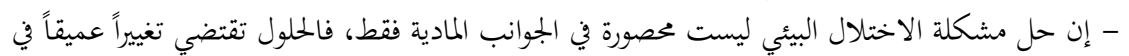

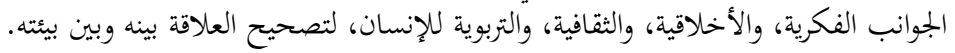
وفي الختام أتقدم بالمقترحات التالية:

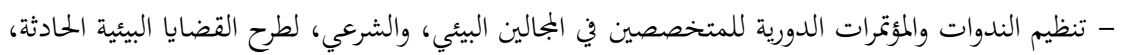
ومناقشة الوسائل والحلول العلمية، والشرعية المناسبة. - انشاء مجمع فقهي متخصص يهتم باستنباط الأحكام، وايجاد الفتاوى المعاصرة للقضايا البيئية. - تأمين الدعم المادي والتقني للدراسات والأبحاث الإسلامية المهتمة بالقضايا البيئية المعاصرة.

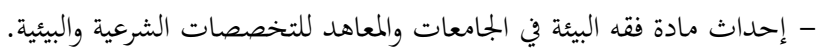

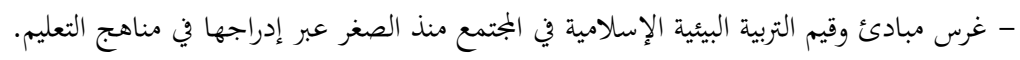




\section{KAYNAKÇA}

Âlu-Borno, Muhammed Sıdkî. el-Vecîz fî îzâhi kavâidi'l-fıkhi'l-külliye. 4. Basım. Beyrut: Müessesetü'r-Risâle, 1416/1996.

el-Âmirî, Ahmed b. Abdulkerîm. el-Ceddü'l-hasîs fî̀ beyâni mâ leyse bi hadîs. thk. Bekir Abdullah. Riyâd: Dâru'r-Râye, 1412/1991.

el-Avedî, Suâd Abdullah. el-Bîe ve't-tenmiyetü'l-müstedâme. Kuveyt: el-Cem'iyyetü'lKuveytiyye li Himâyeti'l-Bîe, 1424/2003.

Azib, Ahmed Muhammed. el-Bîe ve ri'âyetühâ fî dav'i makâsıdi'ş-șerâti's-Suûdiyye. Mü'temeru'l-İslam ve's-Selâm bi Külliyeti'l-Âdâbi Câmiati'd-Dammâm. Suudi Arabistan: Câmiati'd-Dammâm, 1433/2012.

el-Bikâ'î, İbrahim b. Ömer. Nazmü'd-dürer fî̀ tenâsübi'l-âyâti ve's-süver. 22 Cilt. Kahire: Dâru'l-Kitâbi'l-İslâmî, ts.

Buhârî, Muhammed b. İsmâil. el-Edebü'l-müfred. thk. Semîr b. Emîn. Riyâd: Mektebetü'l-Maarif lin-Neşri ve't-Tevzî, 1419/1988.

Buhârî, Muhammed b. İsmâil. Sahîhu'l-Buhârî. thk. Muhammed Zuheyr. 9. Cilt. Beyrut: Daru Tavku'n-Necât, 1422/2001.

Câsim, Nasayyef. Ri'âyetü'l-bîe fi'l-İslâm min mes'ûliyyâti'd-devle. Tikrit: Mecelletü Câmi'ati Tikrit li'l-'Ulûm, Sayı: 4, 1433/2012.

Ebu'l-Ayneyn, Ali Halil. et-Terbiyetü'l-İslâmiyye ve tenmiyetü'l-müctema'i'l-İslâmî. Medîne: Mektebetü İbrahim el-Halebî, 1407/1987.

Ebû Dâvud, Süleyman b. el-Eş 'as. Sünenü Ebî Dâvud. thk. Şuayb el-Arnavut. 7 Cilt. Beyrut: Dâru'r-Risâleti'l-Âlemiyye, 1430/2009.

Ebû Hayyân, Muhammed b. Yûsuf. el-Bahru'l-muhît fi't-tefsîr. thk. Sıdkî Muhammed. 10 Cilt. Beyrut: Dâru'l-Fikr, 1420/2000.

el-Feyyûmî, Ahmed b. Muhammed. el-Misbâhu'l-münîr fî ğarîbi'ş-Șerhi'l-kebîr. Beyrut: el-Mektebetü'l-İlmiyye, ts.

Gazzâlî, Muhammed b. Muhammed. el-Mustasfâ. thk. Muhammed Abdu's-Selâm. Beyrut: Dâru'l-Kütübi'l-İlmiyye, 1413/1993.

Ğânim, Hüseyin Mustafa. el-İslâm ve himâyetü'l-bîe mine't-televvüs. Mekke: Merkezü Buhûsu'd-Dirâsâti'l-İslâmiyye bi Câmiati Ümmi'l-Kurâ, 1418/1997.

Hamza, Mustafa. el-İslâm ve'l-bîe. Ribat: Matbaatü'l-Emniye, 1438/2016.

İbn Așûr, Muhammed bin Tâhir. Makâsıdü'ş-şer'iyye'l-İslâmiyye, thk. Muhammed elHabîb. 3 Cilt. Katar: Vizâratü'l-Evkâf ve'ş-Şuûni'l-İslâmiyye, 1419/2004.

İbn Atıyye, Abdu'l-Hakk b. Gâlib. el-Muharraru'l-vecîz fî tefsîri'l-Kitâbi'l-Azîz, 6 Cilt. Beyrut: Dâru'l-Kütübü'l-'İlmiyye, 1422/2002.

İbn Hanbel, Ahmed eş-Şeybânî. Musnedu'l-Imam Ahmed. thk: Şuayb Arnavut vd. 45 Cilt. Beyrut: Muesesetü'r-Risâle, 1421/2001.

İbn Kesir, İsmail b. Ömer. Tefsîru'l-Kur'âni'l-'Azîm. thk. Sami Selâme. Riyâd: Dâru Taybe li't-Tevzî' ve'n-Neşr, 1420/1999.

İbn Mace, Muhammed b. Yezid. Sünenü İbn Mace. thk. Şuayb Arnavut vd. 5 Cilt. Beyrut: Dâru'r-Risâleti'l-Âlemiyye, 1430/2009.

İbn Manzûr, Muhammed b. Mükrim. Lisânu'l-Arab. 15 Cilt. 3. Basım. Beyrut: Dâru Sâdır, 1414/1993.

İbn Nuceym, İbrahim b. Muhammed. el-eșbâh ve'n-nazâir. thk. Zekeriya Umeyrât. Beyrut: Dâru'l-Kütübi'l-İlmiyye, 1419/1999.

İslam, Ahmed Midhat. et-Televvüs müşkiletü'l-'asr. Kuveyt: Daru'l-Ma'rife, $1411 / 1990$.

el-Karafî, Ahmed b. İdris. Envâru'l-burûkfî envâi'l-furûk. 4 Cilt. Beyrut: Âlemu'l-Kütüb, ts.

el-Kardâvî, Yusuf. Ri'âyetü'l-bîe fî́ş-şerî'ati'l-İslâmiyye. Kahire: Dâru'ş-Şurûk, 
$1421 / 2001$.

el-Kinânî, Muhammed b. İbrahim. Tahrîru'l-ahkâm fî tedbîri ehli'l-İslâm. Thk: Fuad Abdu'l-Mun'im. 3. Basım. Katar: Dâru's-Sekâfe, 1408/1988.

el-Kurtubî, Muhammed Ahmed. el-Câmi' li ahkâmi'l-Kur'ân. thk. Ahmed el-Berdûnî. 2. Basım. 20 Cilt. Kahire: Dâru'l-Kütübi'l-Mısriyye, 1384/1964.

Mâverdî, Ali b. Muhammed. el-Ahkâmu's-sultâniyye, Thk: Ahmed Câd. Kahire: Dâru'lHadîs, 1427/2006.

el-Milîcî, Ahmed Abdu'l-Aziz. et-Tevâzunu'l-bî'î beyne'l-'ilmi ve'l-îmân. Dubai: Câizetü Dubai ed-Devliyye li'l-Kur'âni'l-Kerîm, 1429/2008.

el-Mubârek, Muhammed b. Abdu'l-Azîz. Ri'âyetü'l-bîe min hılâli't-tak'îdi'l-usûliyyi ve'lfikhî. Riyâd: Mecelletü'l-Cem'iyyeti'l-Fıkhiyyeti's-Suûdiyye, 17, 1435/2013.

Müslim, b. el-Haccâc en-Nisâbûrî. Sahîh-u Müslim. thk. Muhammed Fuad Abdulbâkî. 5 Cilt. Beyrut: Dâru İhyâi't-Türâsi'l-Arabiy, ts.

en-Neccâr, Abdu'l-Mecîd Ömer. Kadâya'l-bie min manzûrin İslâmiyyin, 2. Basım. Katar: Vizâratü'l-Evkâf ve'ş-Şuûni'l-İslâmiyye, 1425/2004.

en-Nesâî, Ahmed bin Şuayb. es-Sünenü'l-kübrâ. Thk: Hasan Şelebî. 10 Cilt. Beyrut: Müessesetü'r-Risale, 1421/2001.

Râgıb el-İsfahânî, Hüseyin b. Muhammed. el-Müfredât fî garîbi'l-Kur'ân. thk. Sâfvân Adnân. Dımaşk: Dâru'l-Kalem, 1412/1991.

er-Raysûnî, Ahmed. Nazariyyetü'l-makâsıd 'inde'l-İmam eş-Şâtıbî. 2. Basım. Riyad: edDâru'l-Âlemiyye li'l-Kütübi'l-İslâmî, 1412/1992.

es-San'ânî, Muhammed b. İsmail. Sübülü's-selâm. 2 Cilt. Kahire: Dâru'l-Hadîs, ts.

es-Suyûtî, Abdurrahman b. Ebû Bekr. el-Eşbâh ve'n-nazâir. Beyrut: Dâru'l-Kütübi'lİlmiyye, 1411/1990.

Şâtıbî, İbrahim b. Musa. el-Muvâfakât. thk. Meşhur Âlu Süleyman. 7 Cilt. Kahire: Dâru bin Affân, 1417/1997.

Şihâte, Abdullah. Ru'yetü'd-dîni'l-İslâmî fi'l-hıfâz ala'l-bîe. Mısır: Dâru'ş-Şurûk, $1421 / 2001$.

Zerkâ, Ahmed b. Muhammed. Şerhu'l-kavâidi'l-fikhiyye. Ta'lîk: Mustafa Ahmed ezZerkâ. 2. Basım. Dımaşk: Dâru'l-Kalem, 1409/1989.

Zerkeșî, Muhammed b. Abdullah. el-Bahru'l-muhît fî usûli'l-fikh. 8 Cilt. Kahire: Dâru'lKütübî, 1414/1994.

Zuhaylî, Muhammed Mustafa. el-Kavâidu'l-fikhiyye ve tatbîkâtuha fîlmezâhibi'lerba'a. 2 Cilt. Dımaşk: Dâru'l-Fikr, 1427/2006.

ez-Zu'bî, Isâm Ahmed. el-Bîe min manzûrin terbeviyyin Íslâmiyyin. Risaletü'l-Macister, fî Külliyeti't-Terbiye ve'd-Dirâsâti'l-İslâmiyye, Ürdün: Câmiatü'l-Yermûk, $1422 / 2001$. 